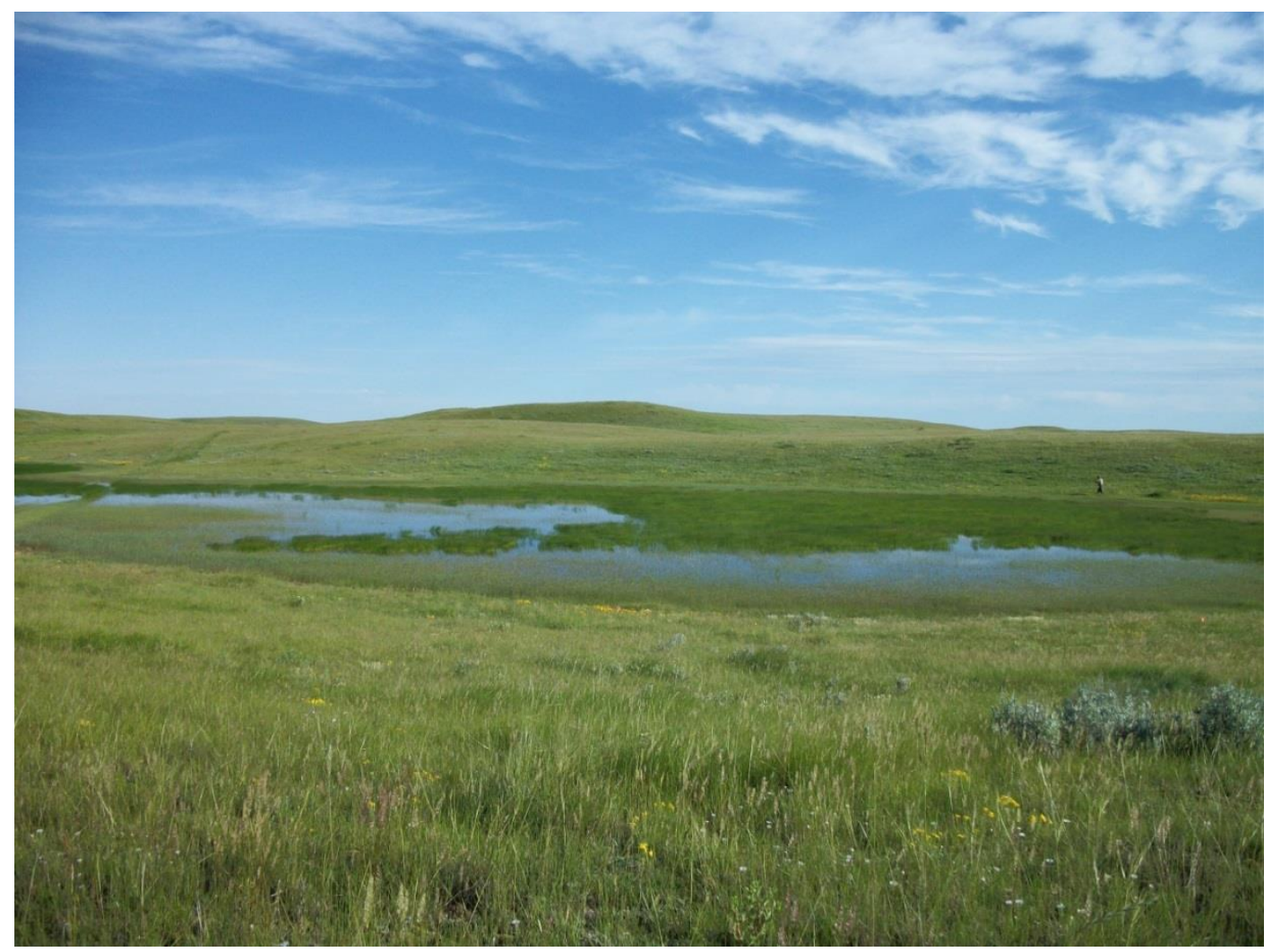

Literature review: Hydrology-ecology relationships in Montana Prairie wetlands and intermittent/ephemeral streams

\author{
Prepared by: \\ Linda Vance \\ Sara Owen \\ Jane Horton
}

Prepared for:

The Cadmus Group, Inc.

U.S. EPA Contract Number EP-C-08-002

May, 2013 


\title{
Literature review: Hydrology-ecology relationships in Montana Prairie wetlands and intermittent/ephemeral streams
}

\author{
Prepared by: \\ Linda Vance \\ Sara Owen \\ Jane Horton
}

Prepared for:

The Cadmus Group, Inc.

U.S. EPA Contract Number EP-C-08-002
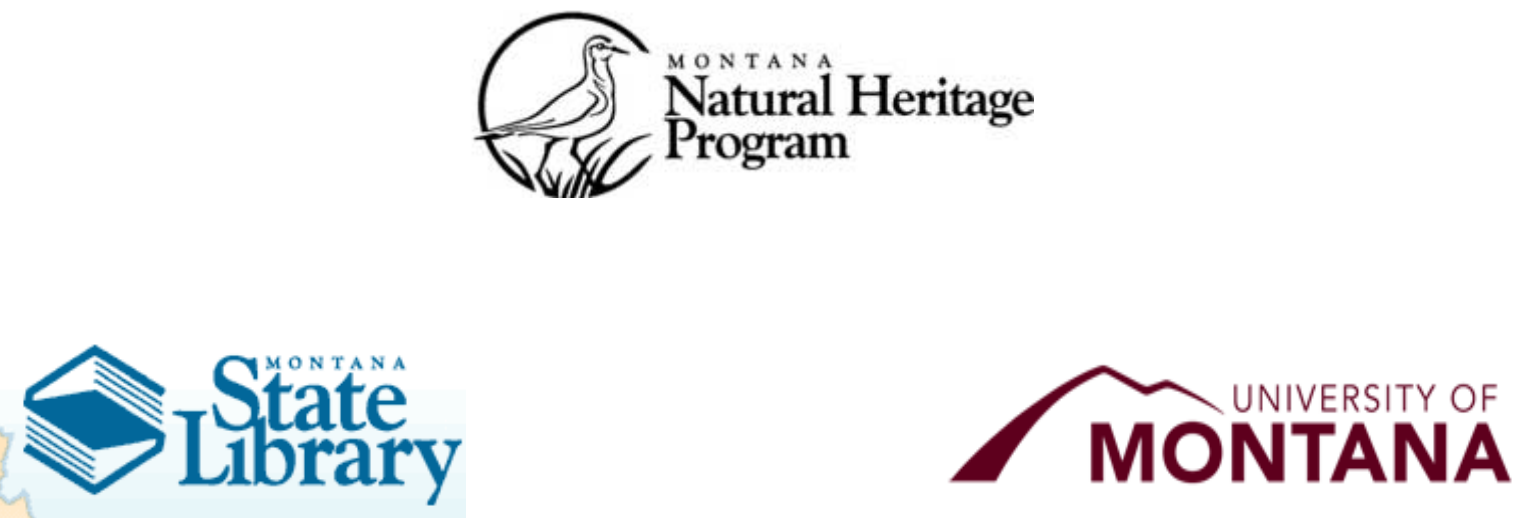

P.O. Box 201800 1515 East 6th Avenue $\cdot$ Helena, Montana 59602-1800 • (406) 444-5354 
This document should be cited as follows:

Vance, L., S. Owen and J. Horton. 2013. Literature review: Hydrology-ecology relationships in Montana Prairie wetlands and intermittent/ephemeral streams. Report to the Cadmus Group and the U.S. Environmental Protection Agency. Montana Natural Heritage Program, Helena, MT. 49 pp. plus appendices. 


\section{Executive Summary}

Numerous published and unpublished studies have examined the relationship between wetland hydrology, wetland processes and functions, and wetland-dependent biota. The goal of the present project was to review existing studies, models, and local expert knowledge to describe hydrology-ecology relations under natural conditions and to generate a systematic characterization of the relationships between hydrologic regimes and biological dependencies of prairie wetlands in Montana. This report describes the scope of the project, provides some of the background information used to frame the literature review, summarizes the methods, and presents and discusses the findings of the review.

The project's broad geographic scope was defined as the Prairie Pothole Region (PPR) of North America, which extends across approximately $715,000 \mathrm{~km}^{2}$ of five US states (Iowa, Minnesota, North Dakota, South Dakota and Montana) and three Canadian provinces (Manitoba, Saskatchewan and Alberta). Within that area, it focuses on the 95,907 $\mathrm{km}^{2}$ Northwestern Glaciated Plains ecoregion of Montana. The topical scope of the project is the pothole wetlands of the PPR, and the intermittent and ephemeral streams present in the region. Because the wetlands of the PPR are so important to North American waterfowl and other migratory birds, the area has attracted substantial research interest. Scientific investigations have been far-ranging, from basin-specific short term studies of specific species and wetland components to long-range, landscape-level analyses and models. Over the years, this has resulted in a more complete, and more nuanced, understanding of ecosystem processes and functions and a better characterization of the inherent variability of the region.

In this report, we begin by describing the Prairie Pothole Region (PPR) and the wetlands and streams that characterize it. We then discuss the methods we used to search for, summarize, and interpret research reports, agency documents, expert knowledge and models. The extreme variability of wetland and stream habitats in the PPR accounts for much of its diversity. In our Results section, we examine how differences between natural and human hydrologic change affect the functions, processes and biota that depend on wetlands and streams, and how this affects regional diversity. This is followed by a summary of the impact of anthropogenic change on a common suite of wetland and stream, notably 1) flood mitigation; 2) water storage and streamflow maintenance; 3) groundwater recharge; 4) sediment retention; 5) nutrient and chemical cycling; 6) plant community maintenance; and 7)maintenance of faunal habitat and biodiversity. In sum, we review over 150 published sources. We conclude that ecological responses to natural changes in wetland hydrology are variable, depending on the direction of change and the species, guild or function affected. For example, droughts generally lead to 
decreases in avian, macroinvertebrate and fish abundance, depending on the extent and duration of the drought. Flood cycles, in contrast, promote both greater abundance and changes in community structure. However, ecological responses to anthropogenic alteration are almost entirely negative. This difference reflects the duration of natural vs. anthropogenic change. Natural hydroperiods of wetlands and prairie streams vary spatially and temporally, with flood and drought cycles altering. In contrast, human manipulations of flood frequency, duration or extent tend to be permanent, as are the changes in wetland function that they induce. The Discussion section sets forth some of the implications of these conclusions, and lays out directions for future research. The Bibliography and Appendices provide more detail about our sources and approach. 


\section{Acknowledgements}

This project was funded through a contract from the United States Environmental Protection Agency to the Cadmus Group, LLC, which subcontracted to the Montana Natural Heritage Program (MTNHP) to carry out the literature review. Thanks are due to Laura Gabanski of EPA Headquarters, Laura Blake of Cadmus, and Lynda Saul of the Montana Department of Environmental Quality for pulling the project together. We were aided by a Technical Advisory Group consisting of Eloise Kendy and Philip Gerla of The Nature Conservancy, Sean Fields of the United States Fish and Wildlife Service, and Lynda Saul, who reviewed drafts of this report and made helpful suggestions, as did Andrew Somor of Cadmus. Peter Ismert of EPA Region 8 also sat in on meetings between the Technical Advisory Group and report authors. In Montana, Beth Dodds of the Montana State Library provided helpful guidance on constructing Boolean search strings. Randy Apfelbeck of the Montana Department of Environmental Quality offered assistance with uncovering unpublished studies. Jamul Hahn of MTNHP designed the map template, and made several of the maps. All photos used in this report come from MTNHP staff. Thanks, too, to the numerous hydrologists, biologists, land managers and others who responded to our requests for information.

Despite the assistance of these and other people, errors may remain; if so, these are entirely the responsibility of the authors. 


\section{Contents}

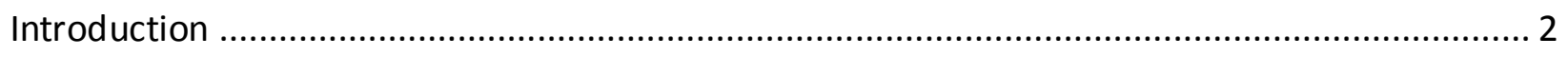

Scope

Background: Prairie Pothole Wetlands and Intermittent/Ephemeral Streams ............................. 5

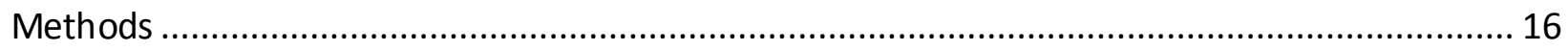

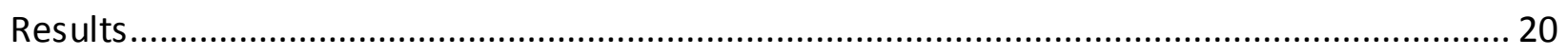

Hydrology-ecology relationships: Natural vs. human disturbance …..................................... 21

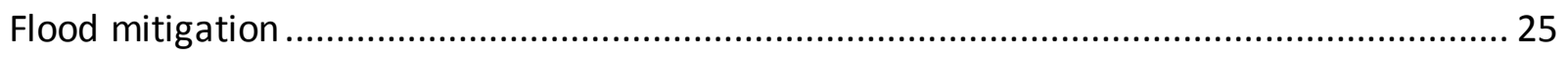

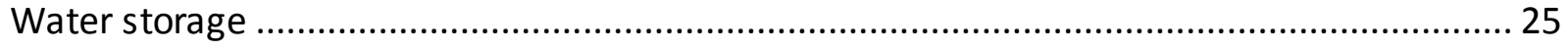

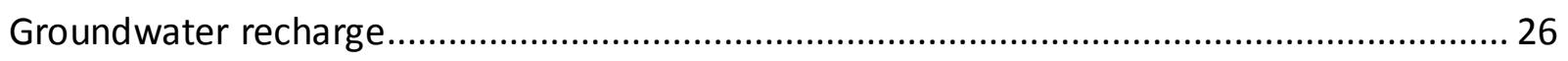

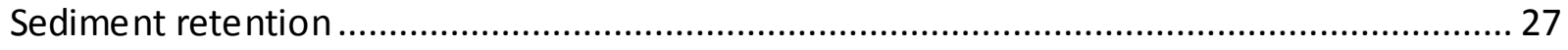

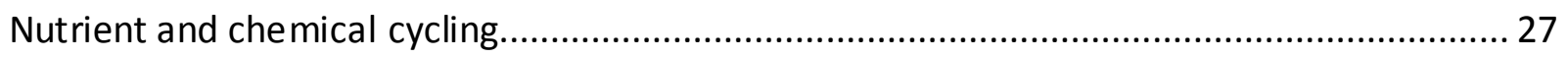

Plant community mainte nance ........................................................................................ 28

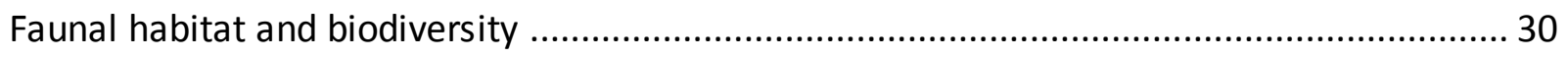

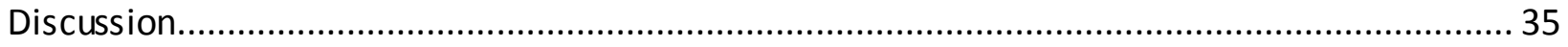

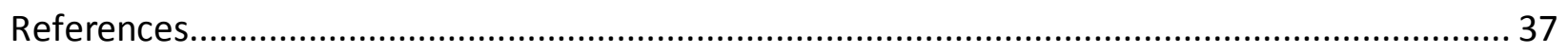

Appendix A. Approximate crosswalk between classification schemes ....................................... 51

Appendix B. Keywords and search strings used in database searches....................................... 52

Appendix C: Faunal species associated with PPR wetland and streams ..................................... 54

Appendix D. Number of sources describing ecological change in wetland function following

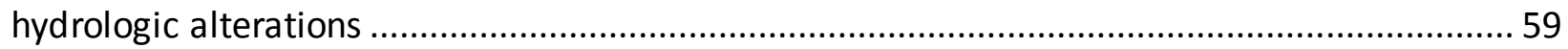




\section{Introduction}

The Ecological Limits of Hydrologic Alteration (ELOHA) framework (Poff et al. 2010) is a flexible approach to identifying appropriate environmental flows at a regional scale, based on existing hydrological and biological knowledge of river types, their associated flow-ecology relationships, and regulatory or voluntary condition goals (Kendy et al. 2012). ELOHA development takes a holistic approach to building a knowledge base about flow-dependent ecological processes and taxonomic groups, drawing on quantitative data, qualitative literature and expert knowledge to build consensus about the ecological limits of hydrologic alteration (DePhilip \& Moberg 2010; McManamay et al. 2011)

Although the ELOHA approach has been adopted throughout the United States to assess and manage environmental flows for rivers (see, e.g., the case studies in the ELOHA toolbox), it has not been used to explore the limits of hydrologic alteration for wetlands, even though it is widely agreed that "hydrology is probably the single most important determinant of the establishment and maintenance of specific types of wetlands and wetland processes" (Mitsch \& Gosselink 2000). In part this is due to the lack of detailed hydrologic data for all but a handful of wetlands. While regional streamflow models can be constructed from data records for a suite of representative sites, no such hydrologic foundation is in place for most wetland areas, and indeed, temporal, spatial, and typological variation in the timing, duration and extent of wetland inundation would make such an effort challenging even if more hydrologic data were available. Nonetheless, numerous published and unpublished studies have examined the relationship between wetland hydrology, wetland processes and functions, and wetlanddependent biota. The goal of the present project is to review existing studies, models, and local expert knowledge to describe hydrology-ecology relations under natural conditions and to hypothesize ecological responses to hydrologic change.

The United States Environmental Protection Agency (EPA) contracted with The Cadmus Group, Inc. and the Montana Natural Heritage Program to generate a systematic characterization of the relationships between hydrologic regimes and biological dependencies of prairie wetlands in Montana. For the first phase of the project, Montana Natural Heritage Program compiled and reviewed ecological and hydrologic literature, existing reports, relevant studies, and available data and summarized the existing knowledge about wetland-dependent biota and ecological processes in eastern Montana. The purpose of this report is to describe the scope of the project, provide some of the background information used to frame the literature review, summarize the methods, and present and discuss the findings of the review. 


\section{Scope}

The project's broad geographic scope was defined as the Prairie Pothole Region (PPR) of North America (Figure 1), which extends across approximately $715,000 \mathrm{~km}^{2}$ of five US states (lowa, Minnesota, North Dakota, South Dakota and Montana) and three Canadian provinces (Manitoba, Saskatchewan and Alberta). As glaciers retreated some 12,000 years ago, they left behind a landscape characterized by rolling hills and as many as $25,000,000$ small wetland basins, generally known as potholes (Winter 1989).

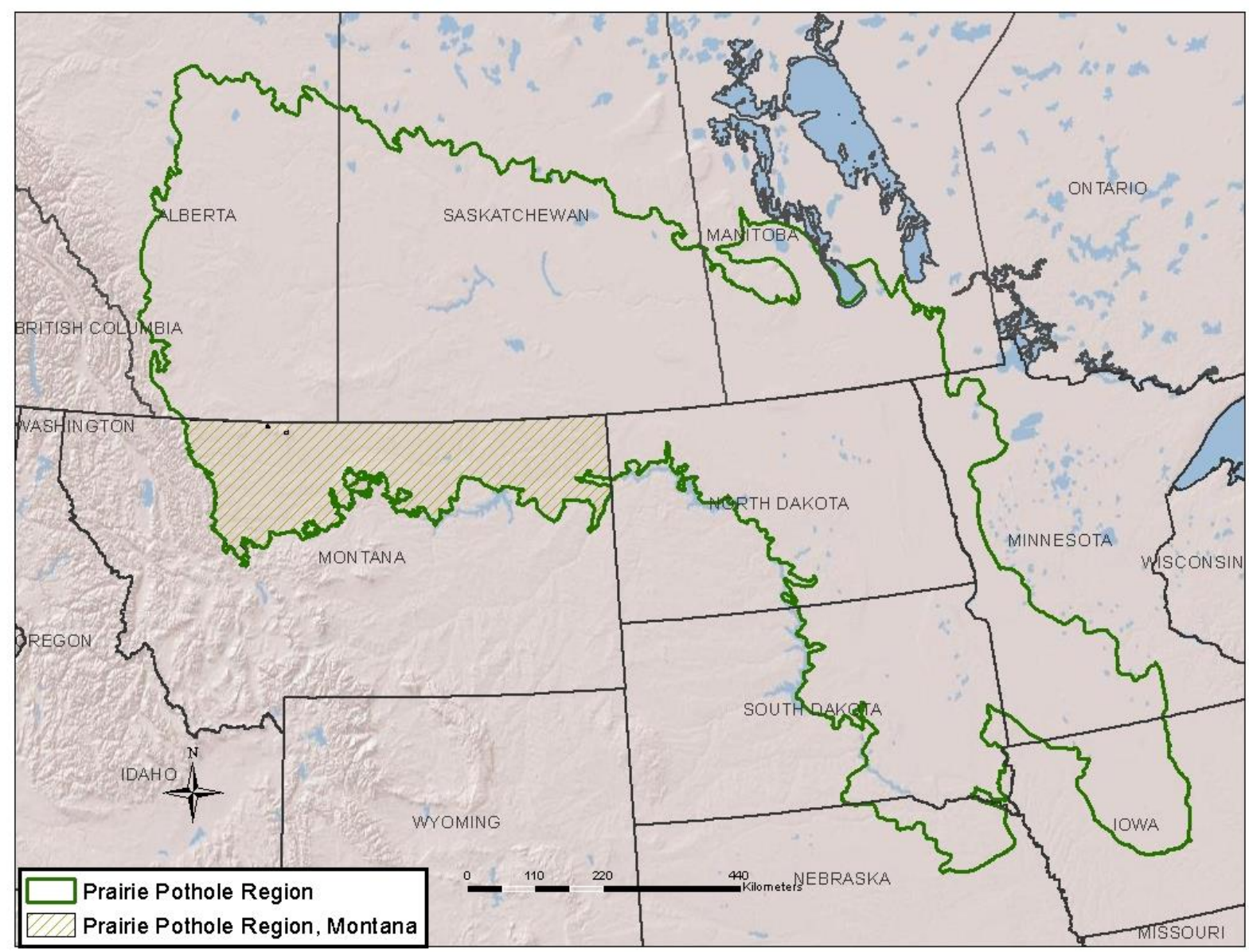

Figure 1. The Prairie Pothole Region

The project focuses on the $95,907 \mathrm{~km}^{2}$ Northwestern Glaciated Plains ecoregion of Montana. Based on historic NWI mapping from the 1980s, which is the most comprehensive mapping available for the entire PPR in Montana, there are 218,000 mapped wetlands, lakes, and river features. Nearly $70 \%$ of the wetlands are temporary or seasonal. Approximately $15 \%$ of the mapped wetlands occur as impounded reservoirs (either temporarily, seasonally, or semipermanently flooded) along intermittent and ephemeral streams. This number has 
undoubtedly increased since the 1980s, as there are numerous small and moderate sized reservoirs visible in recent aerial imagery that were not included in the historic mapping. Over half (56\%) of the mapped wetlands in the PPR are less than one half acre. Nearly threequarters (72\%) of the mapped wetlands are less than 1 acre.

In Montana, glaciation reached its southern extent near the current location of the Missouri River toward the end of the last Ice Age. Consequently, the Montana portion of the PPR has a lighter glacial imprint than some other areas of the PPR, although retreating glaciers still left a layer of till and debris, and carved a the rolling, hilly landscape, dotted with wetlands, similar to that of the larger PPR (US Fish and Wildlife Service 2012a). In the western part of Montana's PPR, along the Rocky Mountain Front, the sedimentary Two Medicine Formation of clay, limestone and sandstone transitions to the shale and siltstone of the Colorado Shale Formation (Figure 2). Here, coarse-textured Pleistocene-era glacial deposits have left areas of hummocky

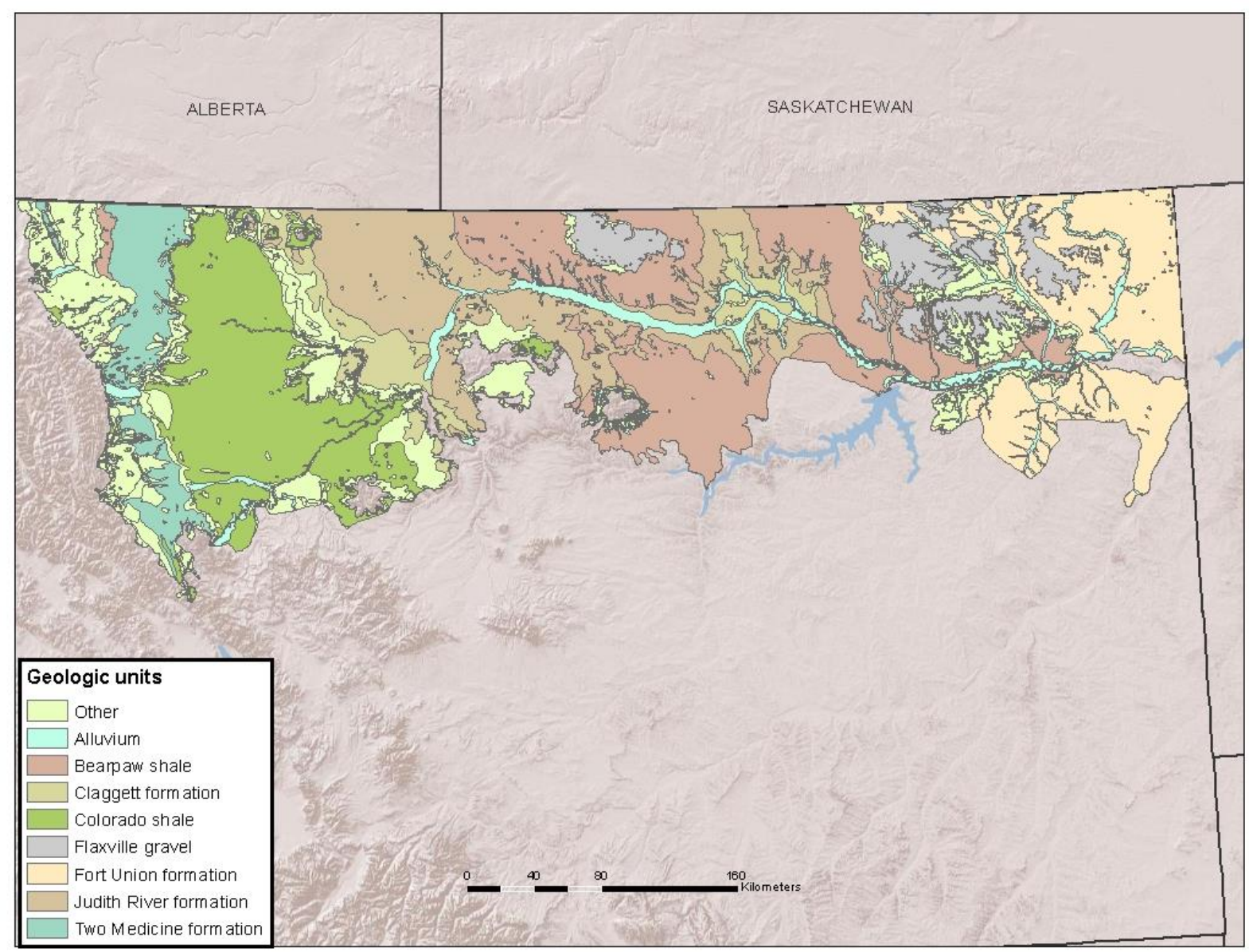

Figure 2. Geology of Montana's Prairie Pothole Region.

pothole wetlands, similar in size to prairie pothole wetlands, but often with more hydrologic permanence. To the east, where the landscape flattens into prairie grasslands, underlying 
bedrock consists of the Cretaceous-era Claggett Formation, Judith River Formation, and Bearpaw Shale, all consisting of almost impervious marine shales, intercalcated with sandstone beds (US Fish and Wildlife Service 2011). Although wetlands are numerous in this area, they tend to be less permanent than those to the west and east. In the east, the Cenozoic era Fort Union Formation, variously made up of claystone, calcareous siltstone, and sandstone, is overlain in parts by glacial Flaxville gravels. Twolarge outwash channels form the Big Muddy and Dagmar valleys, running north to south. The most complex area of Montana's PPR is the Missouri Coteau in the extreme northeast portion of the state, a collapsed moraine with a high density and diversion of potholes and other wetlands (Heidel et al. 2000) that are more similar in terms of vegetation to those in the PPR of North Dakota than to those in the Montana PPR to the west (Hargiss et al. 2008). This is also the western edge of the Williston Basin oil fields (US Fish and Wildlife Service 2007).

The topical scope of the project is the pothole wetlands of the PPR, and the intermittent and ephemeral streams present in the region. Although intermittent and ephemeral streams may connect pothole wetlands during high water periods, they are included here as an independent subject of interest. Like shallow, temporary prairie potholes, they may be overlooked as a landscape feature simply because they are both small and impermanent (Armstrong et al. 2012), but in fact, they perform multiple ecosystem functions in this semi-arid environment. The larger lakes that occur in parts of the area, and the perennial rivers and streams, were not included. These are sufficiently different from pothole wetlands and impermanent streams in their distribution, extent and function that they would be better addressed separately.

\section{Background: Prairie Pothole Wetlands and Intermittent/Ephemeral Streams}

Although multiple wetland classification schemes can be applied to PPR wetlands ${ }^{1}$, the Stewart and Kantrud system, developed specifically for the PPR (Stewart \& Kantrud 1971), was used for this project. Unlike the Cowardin system (Cowardin et al. 1979) used in the National Wetlands Inventory, which allows for multiple and contiguous wetland types with a single depression (e.g., a Palustrine Aquatic Bed wetland with a Palustrine Emergent fringe), the Stewart and Kantrud scheme classifies the entire depression, or basin, and the class is determined by the presence or absence of water in the basin center, with wetlands classified as permanent, semi-

\footnotetext{
${ }^{1}$ See Appendix A for an approximate crosswalk between classification schemes in broad use in the United States.
} 
permanent, seasonal, temporary, or ephemeral (Figure 2$)^{2}$ This classification is widely used in the literature, and employs commonly understood terminology. Most importantly, the Stewart and Kantrud schema best supports the description of flow-ecology relationships. The permanence of water in a wetland, as well as its source and fate also drives the chemical characteristics of the water, particularly salinity, and consequently, vegetation structure and composition and associated food webs. Because hydroperiods can shift over time at site, basin, and regional scales, both from natural and human causes, describing flow-ecology relationships for all wetland types is critical.

Although there is a complex and dynamic relationship between PPR wetlands and local and regional groundwater tables (Labaugh et al. 1998) most pothole wetlands receive the majority of their water from spring snowmelt, with occasional reflooding from summer thunderstorms. However, water permanence is highly variable, both spatially and temporally. In the Stewart and Kantrud system, permanent wetlands have surface water during all years. In semipermanent wetlands, the center of the wetland basin contains surface water during most of the season in most years. The center of a Seasonal wetland basin contains surface water through mid-summer during most years. Temporary wetlands hold water for as little as two weeks during most years, although heavy precipitation during mid-summer can fill the wetland for a brief time. Ephemeral wetlands are small depressions that hold water for less than two weeks only in the wettest years (Figures 2 to 5 ).

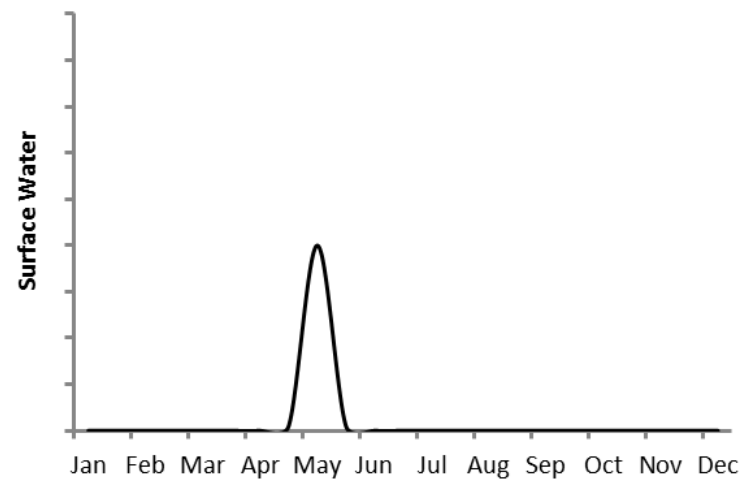

Figure 2. Hypothetical hydrograph of a temporary wetland during an average water year; the same pattern would be seen in an ephemeral wetland in a wet year.

\footnotetext{
${ }^{2}$ Stewart and Kantrud (1971) also include alkali ponds or lakes, and fens in their classification. Because these are rarely described in the literature on the PPR, we did not consider them as part of this review.
} 


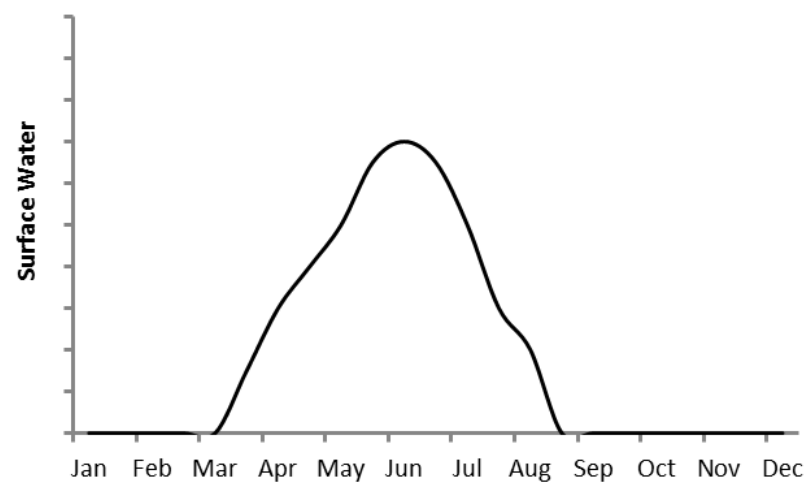

Figure 3. Hypothetical hydrograph of a seasonal wetland during an average water year.

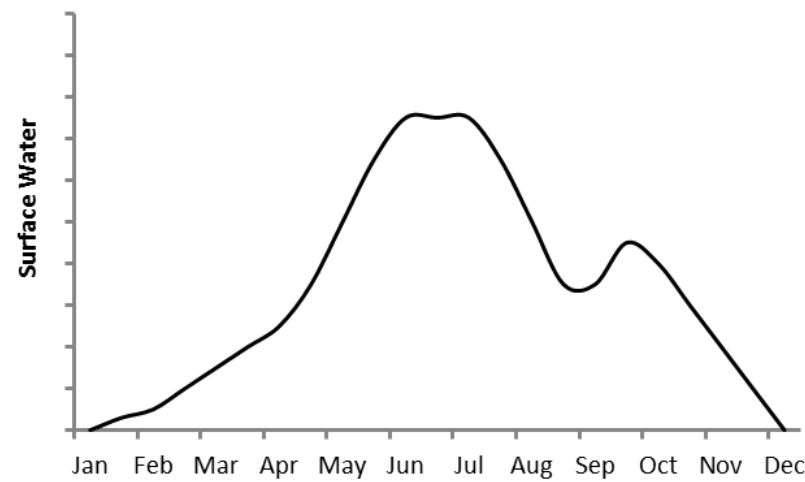

Figure 4. Hypothetical hydrograph of a semi-permanent wetland during an average water year; groundwater supplies a baseflow, and snowmelt runoff and precipitation raise water levels during spring, and autumn rains provide another influx.

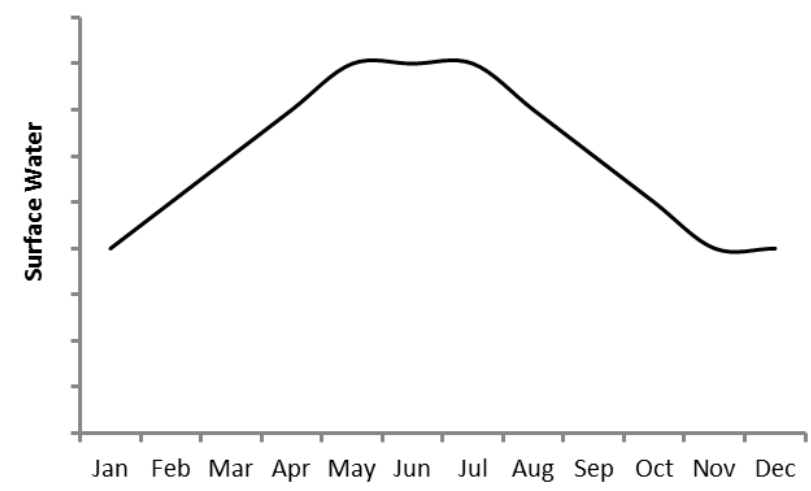

Figure 5. Hypothetical hydrograph of a permanent wetland during an average water year; groundwater supplies a baseflow, and snowmelt runoff and precipitation raise water levels during spring, and autumn rains provide another influx. The balance between precipitation and groundwater influences will depend on wetland size and weather patterns (Roth and Capel 2012) 
Each wetland type has characteristic vegetation patterns, arrayed in generally concentric zones (Figure 6). In permanent wetlands or ponds, a low prairie zone at the outer margin transitions

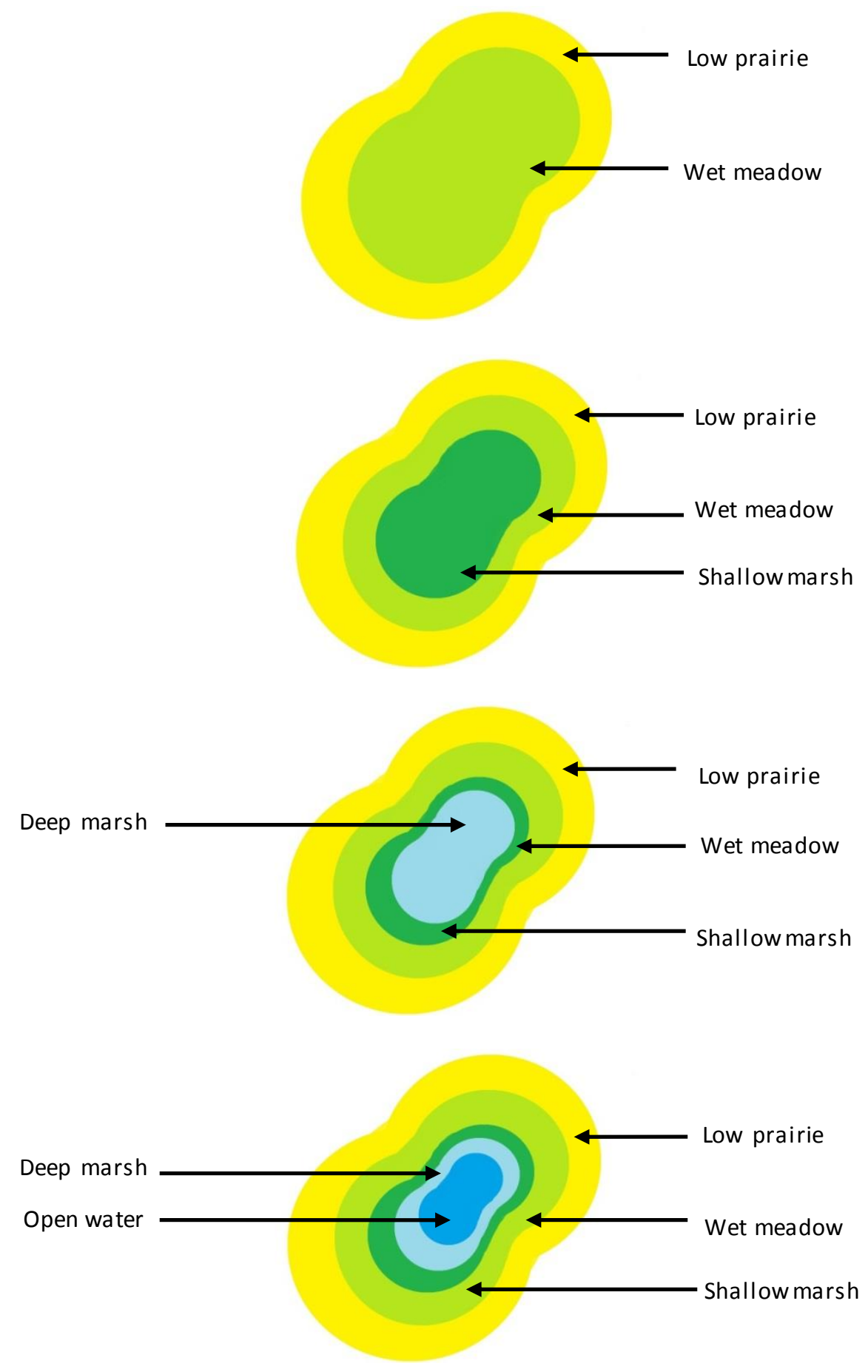

Figure 6: Stewart and Kantrud wetland classes. Top to bottom: temporary wetland; seasonal wetland; semi-permanent wetland; permanent wetland. 
to wet meadow, then to shallow marsh, then to deep marsh, and finally to open water at the center (Figure 7). Temporary wetlands have only an outer low prairie zone and an inner wet meadow zone (Figure 8).

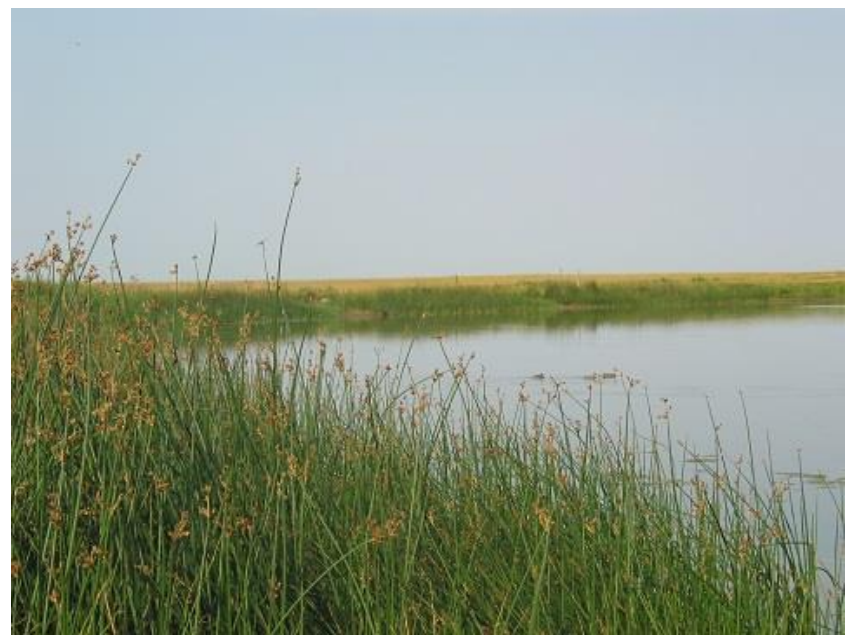

Figure 7. Deep marsh zones adjacent to open water in a permanently flooded wetland

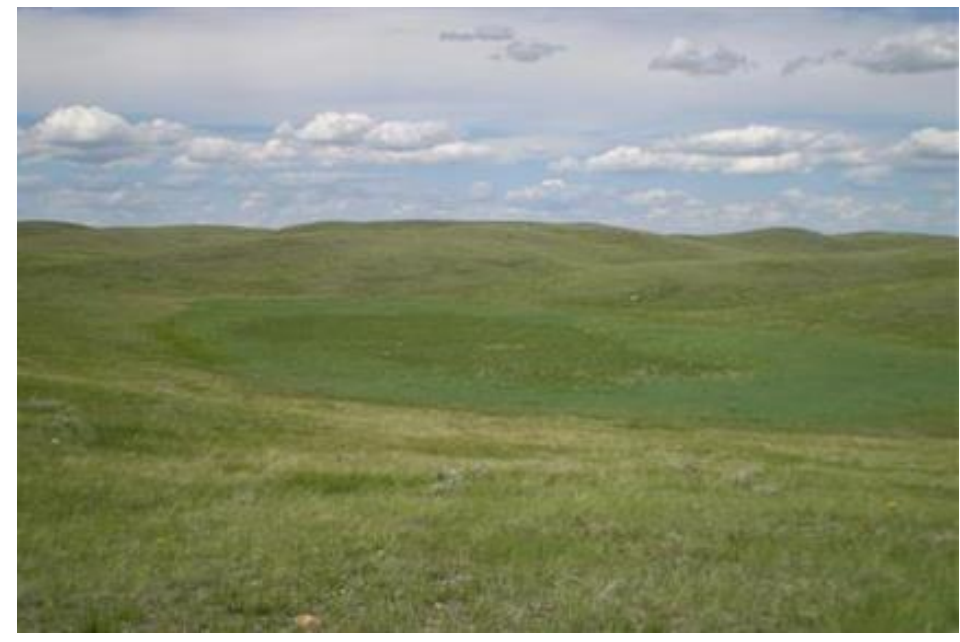

Figure 8. Temporary wetland with wet meadow zonation

Wetlands of the PPR may be groundwater recharge sites, groundwater discharge sites, or flowthrough systems (Winter 1989; but see also van der Kamp \& Hayashi 1998). However, most are 
recharge sites, losing some intercepted snowmelt and rain to groundwater, and the remainder to the atmosphere through evapotranspiration (van der Kamp \& Hayashi 1998).

PPR wetlands typically run a water deficit, with seepage and evaporative loss exceeding inputs. This effect becomes more pronounced along an east-west gradient, with wetlands in the western portion of the region (e.g., Montana, Alberta) being less likely to have season-long water than wetlands in the eastern portion (e.g., lowa). In most of the Montana PPR, for example, less than $5 \%$ of wetlands have semi-permanent or permanent water in typical water years (Figure 9), with the highest concentration along the Rocky Mountain Front and the Little Rockies, and in the Missouri Coteau. Although water regimes are largely driven by substrate and geologic setting, this distribution also reflects the precipitation patterns across the state.

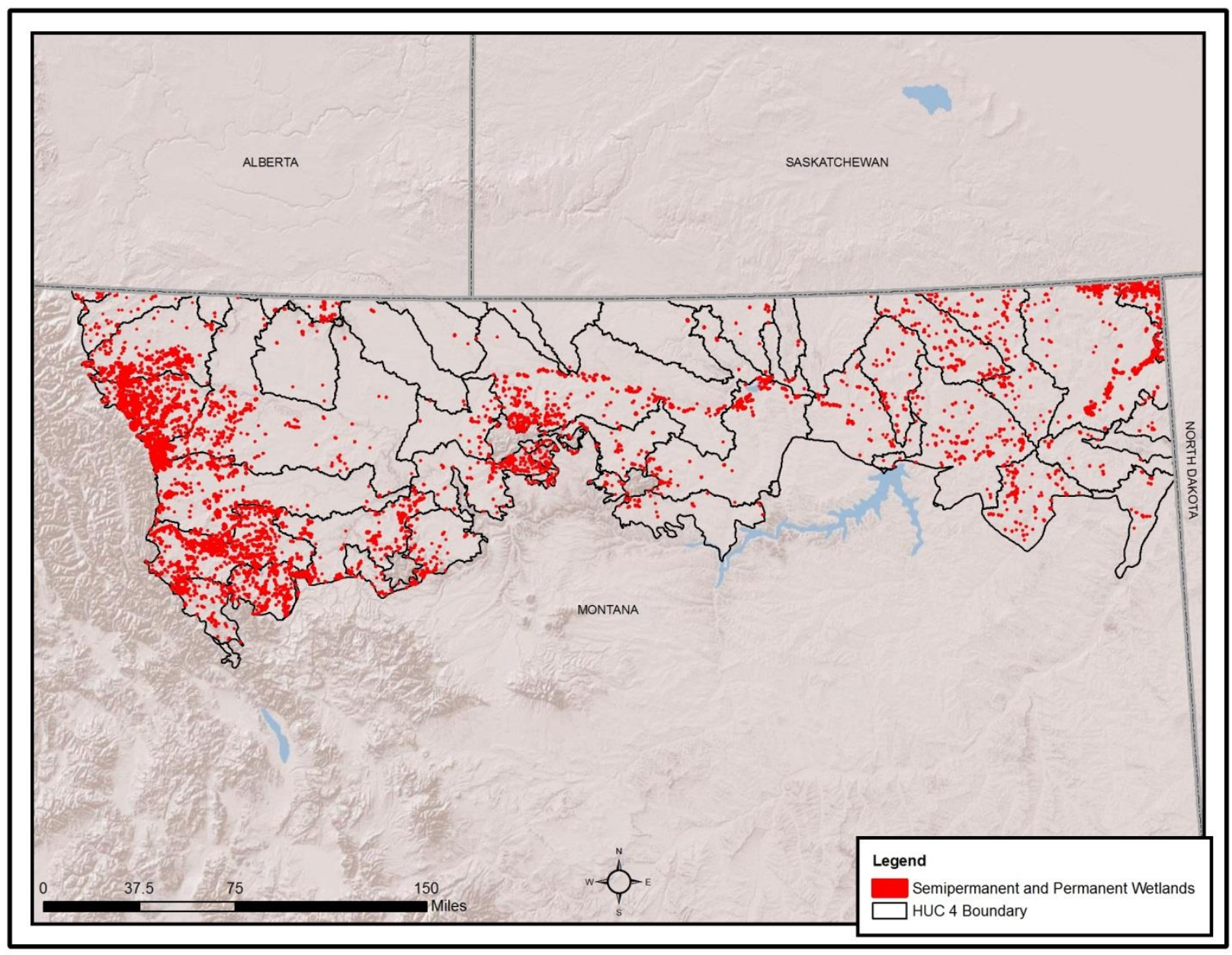

Figure 9. Distribution of semi-permanent and permanent wetlands in Montana, based on 1980s NWI (individual wetland size enhanced for purposes of illustration)

The Missouri Coteau to the east receives the most annual rain, while snow levels are highest in the central and western part of the state (Figure 10). However, these graphs do not capture 


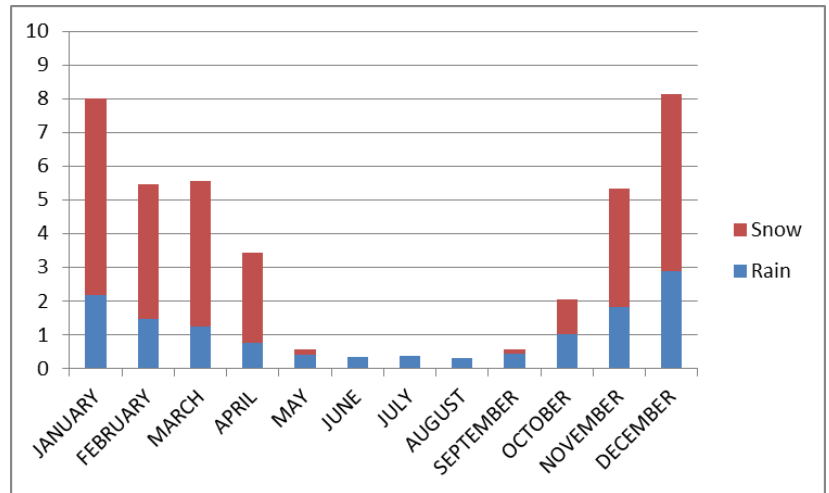

Medicine Lake, Montana

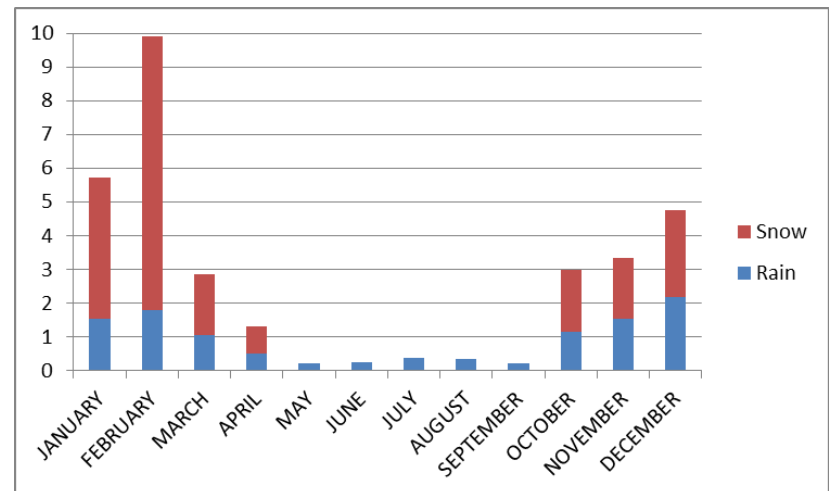

Havre, Montana

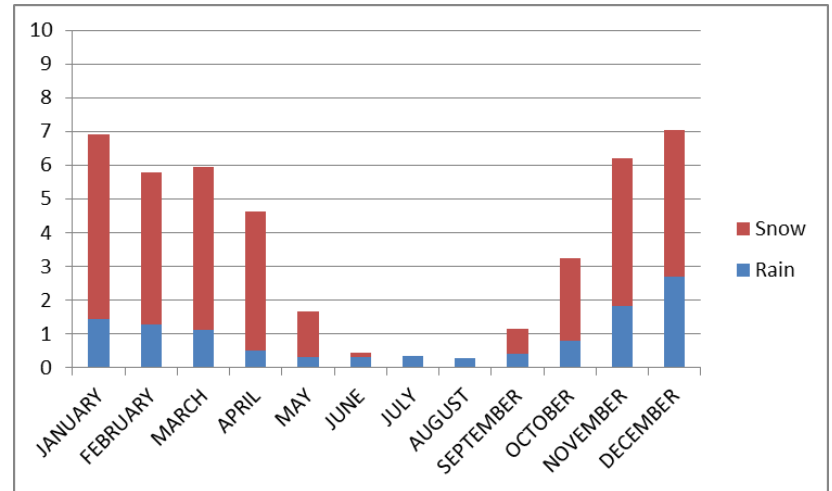

\section{Cut Bank, Montana}

Figure 10. Average precipitation and snowfall across Montana PPR from east (Medicine Lake) to center (Havre) to west (Cut Bank), in inches. Source: Western Climate Science Center

the significant hydrologic inputs to westernmost PPR wetlands from snowmelt originating in the steep catchments along the Rocky Mountain Front. In general, semi-permanent and permanent wetlands are more likely to have a groundwater connection than seasonal or temporary wetlands. However, in extremely wet periods, wetlands that are typically 
precipitation-fed may also have some groundwater flow. Conversely, during drought years, precipitation-fed wetlands may "disappear," and be dominated by low prairie vegetation, while wetlands that are semi-permanent in wet years may lose groundwater connection, and be seasonally flooded only, if at all (Shjieflo 1968; van der Valk 2005; Kahara et al. 2009).

The most detailed study of hydrologic variability in PPR wetlands was carried out by Niemuth et al. (2011) from 1988 to 2007 in 40,000 wetland basins in North and South Dakota and eastern Montana. Using fixed-wing aircraft, the researchers collected aerial photographs of all wetlands in $10.4 \mathrm{~km}^{2}$ sampling blocks ( $n=263$ to 380) during May of each project year. The circa 1980 National Wetland Inventory was used as a baseline for wetland extent under "optimum" water conditions, and wet area for each wetland site within the sampling block was calculated as a percentage of the corresponding NWI polygon. The percentage of wetland basins with water varied from year to year for all wetlands in the study area. In drought years (1988-1992 and 2002 -2005), less than $20 \%$ of temporary wetlands had water during May, while in deluge years (1993-2001), as many as 50\% of temporary wetlands were wet. This variability was also seen on a spatial scale; from year to year, the wet area percentage of basins varied across the study area, with no observed east-west gradient. Although climate variability explained some of the observed patterns, there was enough variability across space and among water regimes to suggest other factors were at play. Other studies have documented the influence of land use (Voldseth et al. 2007), soil types (Gleason and Euliss 1998), catchment size and wetland density (Kahara et al. 2009) on wetland water levels.

Like wetlands, streams in the Prairie Pothole Region are characterized by relatively frequent and random flooding and drying events, which are reflected in temporally variable turbidity and water chemistry (Mullen et al. 2011). Intermittent streams typically have both surface water and groundwater sources, even though they do not flow continuously year round. These lowgradient, sinuous channels will often lose flow in shallow riffle areas by midsummer, appearing as a series of small pools connected by subsurface flows (Figure 11). Ephemeral streams have no groundwater source, and flow only during snowmelt or in response to precipitation events (Figure 12). In some drainage basins, ephemeral channels feed intermittent streams, but in others, flows dissipate before reaching any more permanent water bodies. In both kinds of prairie streams, water exchanges between groundwater and surface waters are common. Ephemeral streams typically have thin alluvial deposits, and maintain water tables below their channels only when precipitation is frequent and heavy. Flows 


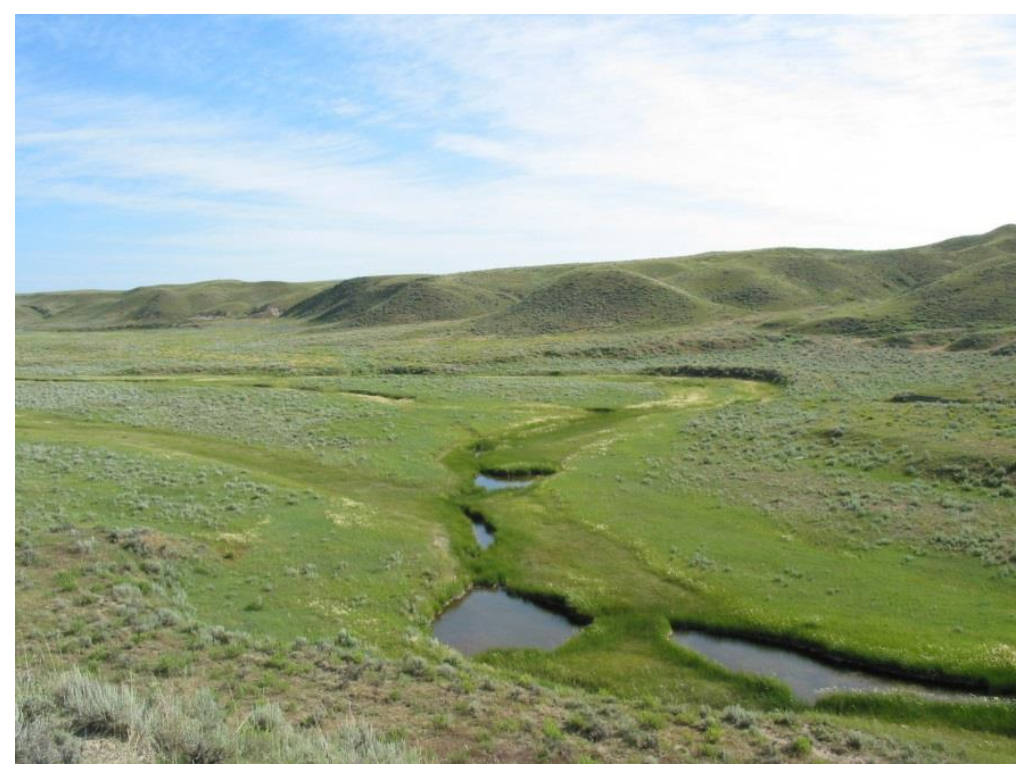

Figure 11. Intermittent Little Sandy Creek, Choteau County, Montana, appearing as a series of pools.

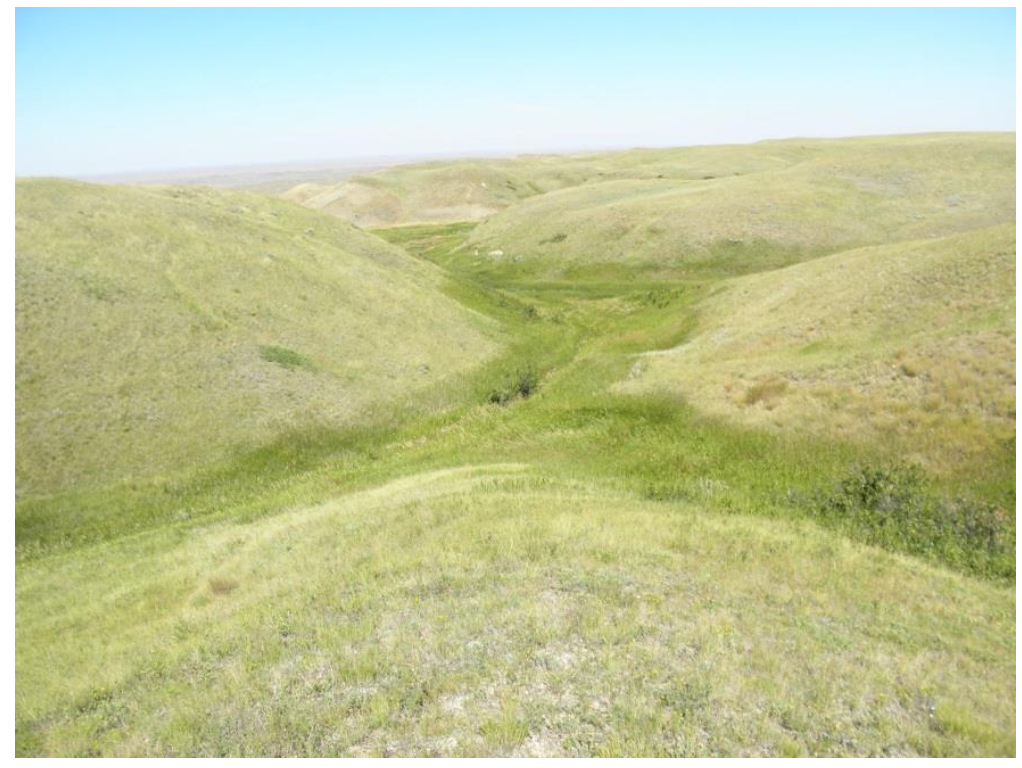

Figure 12. Ephemeral stream, Valley County, Montana.

diminish rapidly along the downstream gradient, with large transmission losses producing shallow groundwater recharge (Shaw \& Cooper 2008). In areas where silts and clays effectively seal surfaces, however, streambeds may remain moist just below the surface for several days. Intermittent streams are often fed by shallow groundwater spreading laterally from wetlands, ponds and lakes due to the impermeable nature of clays and silts in the glacial till (Preston 
2011). Some vertical migration occurs, but it is much more restricted compared to the lateral migration.

Both ephemeral and intermittent streams occur throughout the PPR, often in the broad coulees that drain alluvial flats, and sometimes connect potholes in isolated basins. Nevertheless, the number of stream miles in each category cannot be ascertained easily. The United States Geological Survey has produced a digital NHD from topographical maps, but ephemeral streams are lumped together with intermittent streams. Moreover, the gentle, rolling topography of the area is not easily captured on $10 \mathrm{~m}$ digital elevation models (the best commonly available), so drainage paths are difficult to predict. However, Vance (2009) developed a GIS model that provided estimates of each class for Montana, based on channels that have been digitized from 1:24,000 topographic maps for the National Hydrography Dataset. That model categorized $28 \%$ of stream reaches in the Northwest Glaciated Plains ecoregion as intermittent, while some $64 \%$ of reaches were either ephemeral or had such low flows that they were not even represented in 1:100,000 topographical maps. Across all $4^{\text {th }}$ code Hydrologic Units (HUC 4) in the Montana PPR, only $7.26 \%$ of National Hydrography Dataset (NHD) stream reaches were classified as permanent. As is true with permanent and semi-permanent wetlands, most were along the Rocky Mountain Front or Little Rockies, or in the Missouri Coteau. Figures 13, 14 and 15, based on Vance (2009), show the distribution of ephemeral, intermittent and perennial streams, respectively.

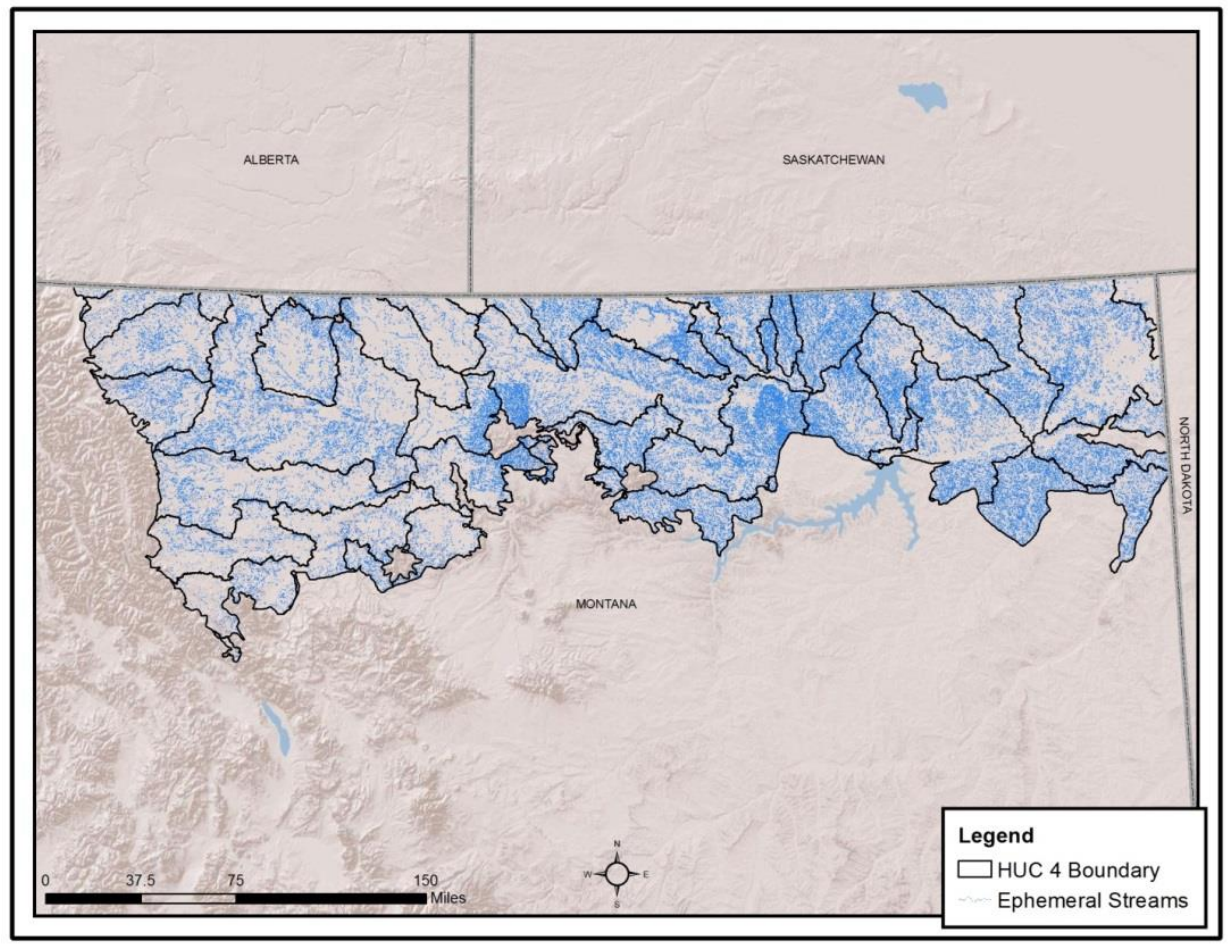

Figure 13. Ephemeral or very low-flow intermittent streams in Montana's PPR 


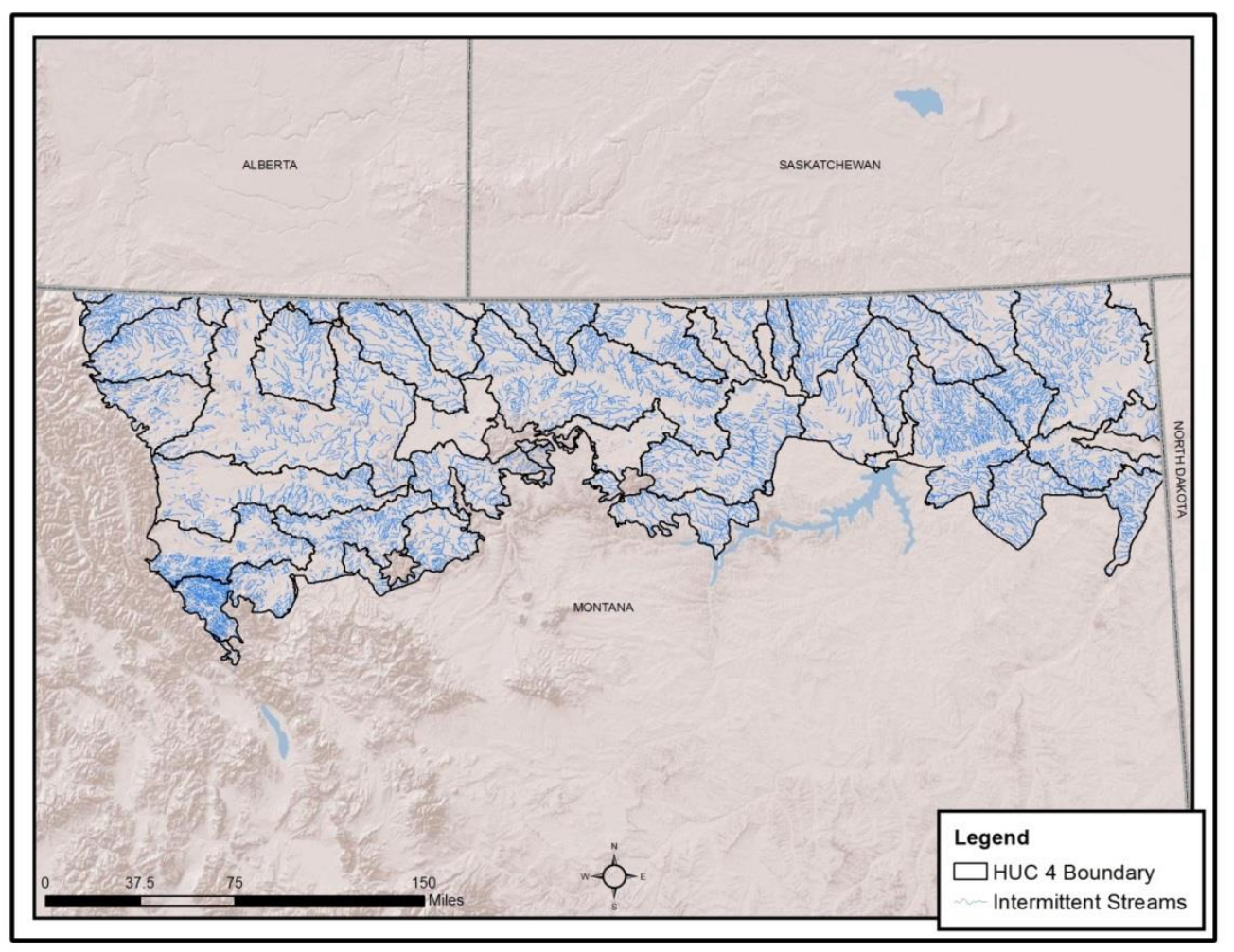

Figure 14. Intermittent streams in Montana's PPR

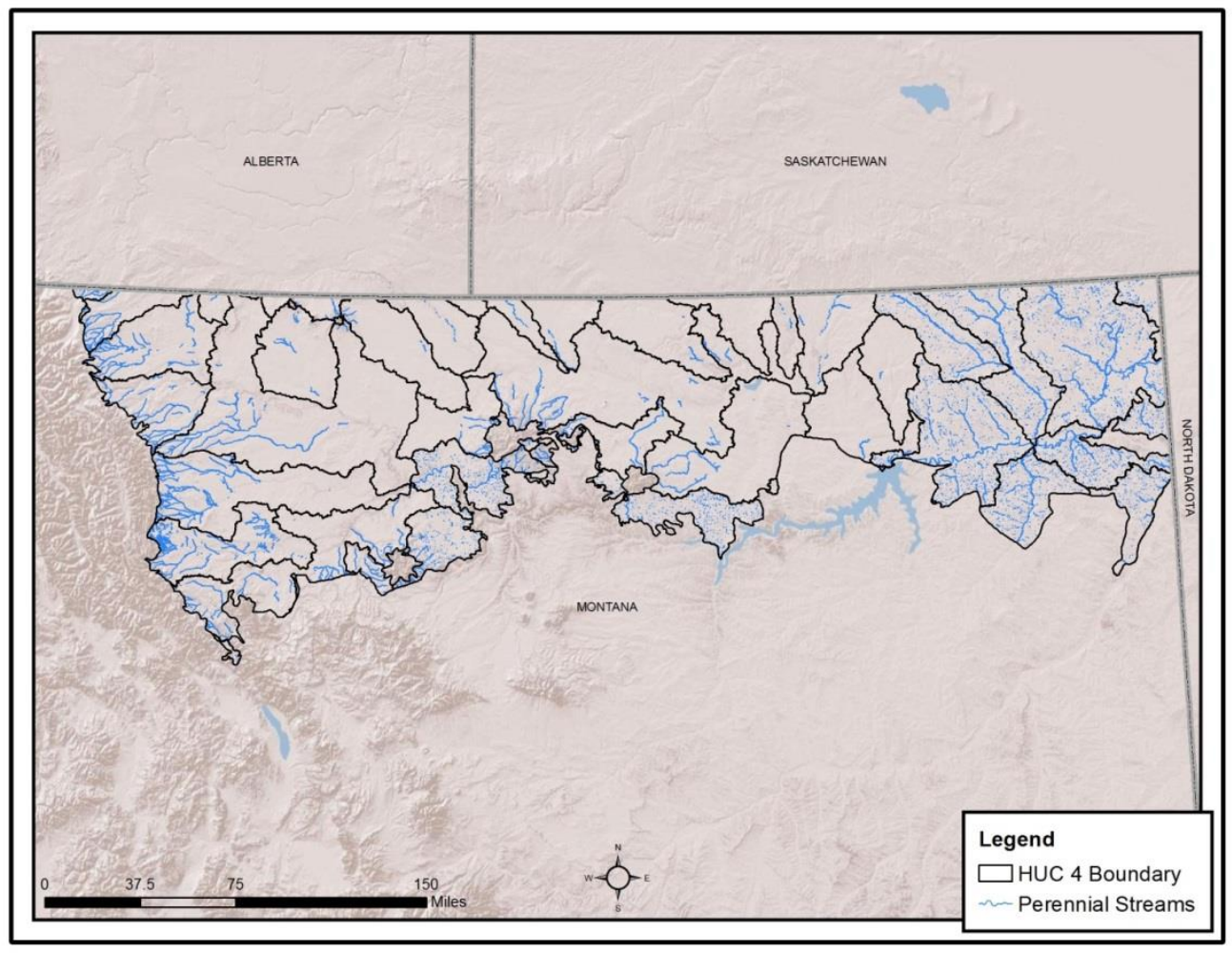

Figure 15. Perennial streams in Montana's PPR. 
Although Montana's PPR is sparsely populated, human activities have a large footprint. Management plans for three of the four Wildlife Refuges operating in Montana's PPR note the challenges posed by agriculture, oil, gas, and other human development activities (US Fish and Wildlife Service 2012b; US Fish and Wildlife Service 2011; US Fish and Wildlife Service 2007), noting their contribution to wetland loss and deterioration ${ }^{3}$ through direct disturbance and infrastructure development. While PPR biota have adapted to natural cycles of drought and inundation, water use associated with the growth of extractive industries and changes in agriculture may alter these cycles in as-yet unanticipated ways, and long-term impacts of climate change are uncertain.

Because the wetlands of the PPR are so important to North American waterfowl and other migratory birds, the area has attracted substantial research interest. Scientific investigations have been far-ranging, from basin-specific short term studies of specific species and wetland components to long-range, landscape-level analyses and models. Over the years, this has resulted in a more complete, and more nuanced, understanding of ecosystem processes and functions (Gilbert et al. 2006) and a better characterization of the inherent variability of the region. Despite the uncertainty associated with future large-scale land use change, it should be possible to extrapolate from what is known about hydrology-ecology relations under natural and altered conditions on smaller scales to predict what may occur on basin- and region-wide scales, and to articulate precautionary limits of hydrologic change. That was the focus of this literature review.

\section{Methods}

A modified causal criteria analysis method (Norris et al.2008, Greet et al. 2011) was used to frame a systematic search of literature on hydrology-ecology relationships in wetlands and intermittent/ephemeral streams of the PPR. Causal criteria analysis follows an 8-step approach, beginning with identifying a broad question (Step 1) and selecting a geographic context for the question (Step 2). The goals and scope of the project -determining how PPR wetland processes, functions and biota respond to changes in the frequency, scope and duration of inundation, whether natural or anthropogenic-addressed the first two steps. Step 3 in the process involves developing a conceptual cause-and-effect model, and Step 4 includes documenting the potential causes and effects that will be explored. Drawing on a preliminary review of the literature and our own knowledge of PPR wetlands and floodplain systems, a conceptual model that included potential causes and effects was constructed (Figure 16 and Table 1).

\footnotetext{
${ }^{3}$ The mineral estate on the fourth Refuge, the Charles M. Russell National Wildlife Refuge, was withdrawn for 20 years in 1993, and there is a current effort to extend the withdrawal (US Fish and Wildlife Service 2012b).
} 


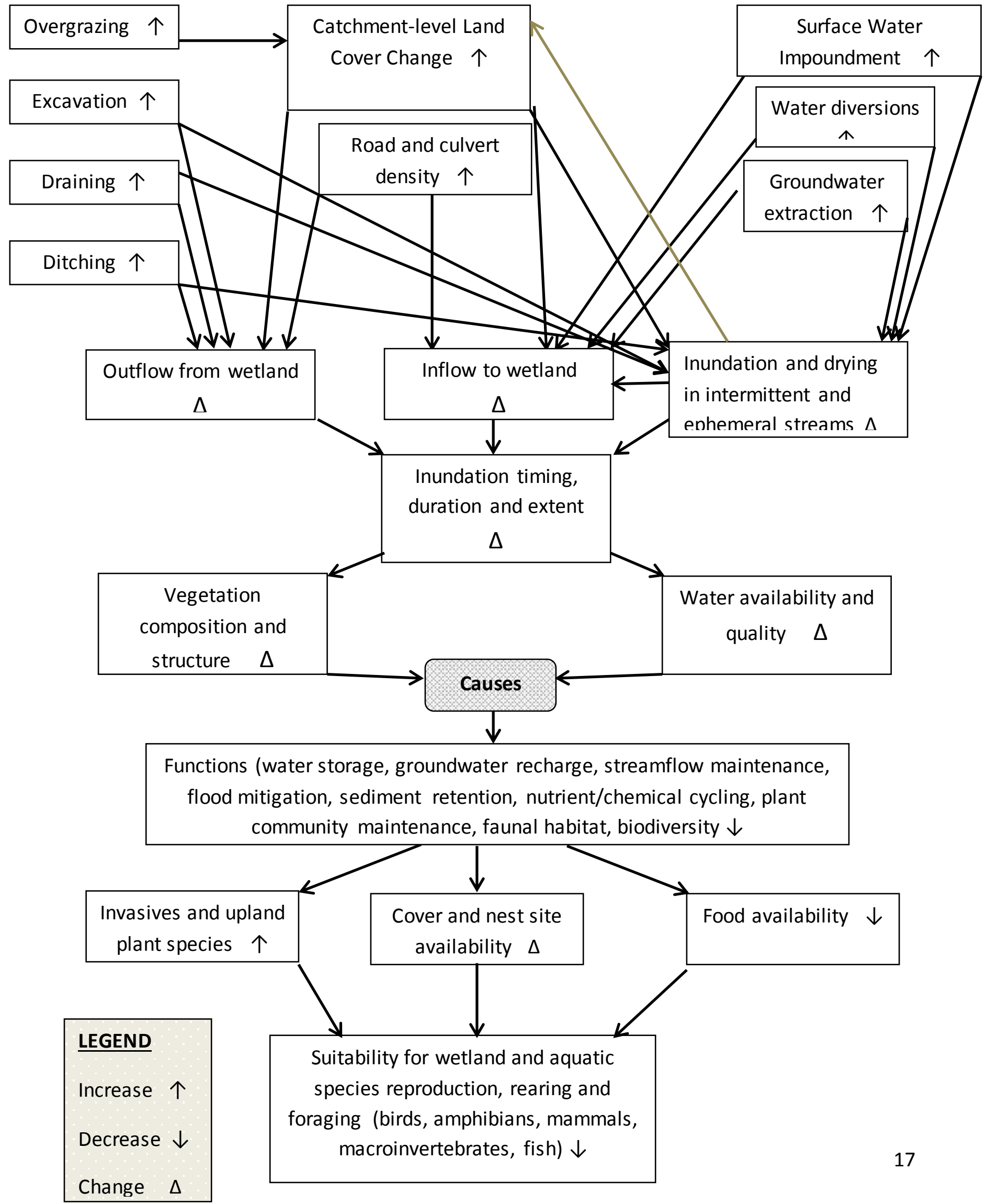


Table 1. Hydrology-ecology causes and effects chosen for investigation

\begin{tabular}{|c|c|c|}
\hline Hydraulic alteration & Hydrologic change & Ecological effect \\
\hline $\begin{array}{l}\text { Inflow diversion or } \\
\text { impoundment }\end{array}$ & $\begin{array}{l}\text { Decreased extent, duration or frequency of } \\
\text { inundation }\end{array}$ & $\begin{array}{l}\text { Loss of biotic and abiotic } \\
\text { function }\end{array}$ \\
\hline Groundwater extraction & $\begin{array}{l}\text { Decreased extent, duration or frequency of } \\
\text { inundation }\end{array}$ & $\begin{array}{l}\text { Loss of biotic and abiotic } \\
\text { function }\end{array}$ \\
\hline Outflow impoundment & $\begin{array}{l}\text { Increased extent, duration or frequency of } \\
\text { inundation }\end{array}$ & $\begin{array}{l}\text { Loss of biotic and abiotic } \\
\text { function }\end{array}$ \\
\hline Draining or ditching & $\begin{array}{l}\text { Decreased extent, duration or frequency of } \\
\text { inundation }\end{array}$ & $\begin{array}{l}\text { Loss of biotic and abiotic } \\
\text { function }\end{array}$ \\
\hline Excavation or dredging & $\begin{array}{l}\text { Increased extent, duration or frequency of } \\
\text { inundation }\end{array}$ & $\begin{array}{l}\text { Loss of biotic and abiotic } \\
\text { function }\end{array}$ \\
\hline $\begin{array}{l}\text { Loss of upland native } \\
\text { vegetation }\end{array}$ & $\begin{array}{l}\text { Increased extent, duration or frequency of } \\
\text { inundation }\end{array}$ & $\begin{array}{l}\text { Loss of biotic and abiotic } \\
\text { function }\end{array}$ \\
\hline $\begin{array}{l}\text { Increase in upland road } \\
\text { density }\end{array}$ & $\begin{array}{l}\text { Changed extent, duration or frequency of } \\
\text { inundation }\end{array}$ & $\begin{array}{l}\text { Loss of biotic and abiotic } \\
\text { function }\end{array}$ \\
\hline
\end{tabular}

The literature review (Step 5) covered both anthropogenic and natural (e.g., drought-induced) changes to hydrology, which often differ in scope, extent, and severity. For example, drought and deluge cycles will affect all wetlands and streams within a given basin or complex, while human activities (depending on their nature) may only affect some. Therefore, for each piece of information reviewed, it was noted whether the change agent was natural or anthropogenic. A wide array of possible ecological responses was also examined, such as shifts in physiochemical functioning within wetlands; changes in the abundance, biotic integrity and community composition of vegetation; and differences in survival, reproductive success and behavior in faunal species.

To find peer-reviewed published literature, literature searches were conducted using BioOne and Environment Complete. These databases were chosen because they capture a range of fields, including environmental policy and agriculture, as well as hydrology and ecology. The list of keywords and search strings used is included in Appendix B. The Montana Natural Heritage species occurrence databases were searched to develop a list of all faunal species associated with PPR wetland and stream ecosystems. Occasional or accidental species were excluded from the final list (Appendix C). Each species was used as a search term. 
Grey literature was researched in the United States Geological Survey (USGS) Publications Warehouse (http://pubs.er.usgs.gov/) and in the online Catalog of U.S. Government Publications (http://catalog.gpo.gov). Google and Google Scholar were used to find other governmental and non-governmental reports, theses and dissertations. Reports from advocacy groups, or online papers prepared by undergraduate students were excluded from the review.

Unpublished results, studies, and models were investigated by contacting people suggested by the project's technical advisory group ${ }^{4}$, and others known to be involved with research on PPR wetland and floodplain issues. Management plans from the four USFWS wildlife refuges in Montana's PPR (Benton Lake NWR, Bowdoin NWR, Medicine Lake NWR and Charles M. Russell NWR) were reviewed, as were plans from the Bureau of Land Management, which has extensive land holdings in the area.

All data sources located through the search were given a preliminary review to assess relevance to the current study in terms of 1) geographic scope and 2) inclusion of some element of the hypothesized cause and effect relationships. Preference was given to studies and reports from the PPR, as well as studies and reports that reference hydrologic change as a causal factor in the phenomenon under investigation. This led to the exclusion of some sources. For example, a study on the role of tiger salamanders in PPR wetland food webs (Benoy 2008) was excluded because it had no link to hydrology, as was a study reporting on the relative efficacy of avian species survey approaches in the PPR (Niemuth et al. 2006). Studies on biocriteria development were similarly excluded if they subsumed hydrologic modification into general human disturbances, rather than investigating specific causes and effects (e.g., Apfelbeck 1999; Jones 2004).

References retained for further analysis were recorded in a Microsoft Access database, with a front-end data entry interface to ensure that every reviewer recorded the same information in a consistent way. For each source found through a database search, the search string was recorded, and a unique identifier was assigned to the article. A "Notes" section allowed the reviewer to enter a synopsis of the source's findings or to highlight salient conclusions, record the geographic location, and make other observations about the source. Defined entry fields with drop down menus limited the response recorded. Entry fields included study design, number of control or reference sites, number of sample or impact sites, direction of impact, wetland class affected, lifeforms affected, vegetation response, water quality/quantity response, soil impacts, stressors, affected functions, inflow or outflow affected; timing of inundation, extent of inundation, and duration of inundation.

\footnotetext{
${ }^{4}$ Lynda A. Saul, Montana Department of Environmental Quality; Philip J. Gerla, The Nature Conservancy; Sea n Fields, US Fish and Wildlife Service; and Eloise Kendy, The Nature Conservancy.
} 
The primary goal was to summarize impacts of hydrologic alteration on wetland and stream functions, processes and biota. In a full causal criteria analysis, each source is weighed in terms of the support it provides for some element of the cause and effect hypothesis, with weights allocated based on study design and analysis. For example, a before-and-after impact design with a control $(\mathrm{BACl})$ is generally given more weight than a study that only investigates responses to an impact affecting a single site. Most of the sources reviewed for this project reported on observations or models, rather than the results of controlled experiments. Like rivers, wetlands and streams are challenging systems from an experimental design perspective, because of their spatial heterogeneity, temporal variability, and network connectivity (Konrad et al. 2011). Therefore, after consultation with project technical advisers, it was decided that the studies reviewed would not be weighted individually at this time. Instead, general conclusions from the literature are reported, and in the overall trend of support for different elements of the conceptual model is evaluated in the Discussion section.

The Results section, below, describes sources, summarizes the general hydrology-ecology relationships described in the literature review, and specifically examines ways in which hydrologic alteration (cause) has been shown to affect function, processes and biota in wetlands and streams (effects). The inferences that can be drawn from this review are included in the Discussion section, along with questions requiring further examination.

\section{Results}

Our searches yielded over 200 potential sources. Of these, we found 150 unique sources relevant to our review, including 115 peer-reviewed articles, 22 reports by federal or state agencies, 4 master's theses, 4 management plans, 2 posters, 1 conference proceeding, and 2 books. We found 65 sources dealing with hydrologic impacts on abiotic functions in Prairie Pothole wetlands and intermittent and ephemeral streams (43 peer-reviewed publications, 12 reports, 4 management plans, 3 theses, 2 books, and 1 proceeding). Six additional sources, all from peer-reviewed journals, focused on potential impacts of climate change on wetland hydrology. We also reviewed 21 sources focusing on wetland and stream vegetation (15 from peer-reviewed journals and 6 agency reports).

Eighteen of the sources on abiotic function, climate change and vegetation dynamics were literature reviews, without new data. Fifty-five of the studies reported on data collected in field surveys or inventories. Fourteen sources reported on models, either constructed following field surveys carried out in support of the model, or built on existing data. Three involved analyses of existing data with no new data collection

Faunal habitat requirements and responses to disturbance were by far the most common topic of study encountered in our review, with waterfowl, shorebirds and other avian species the 
fauna most frequently investigated. Thirty of the sources examined habitat requirements or disturbance responses for particular species of waterfowl or shorebirds; eight covered waterfowl and shorebird habitat more generally. An additional 10 sources covered multiple faunal species associated with wetlands or streams. Fourteen sources focused on macroinvertebrates; 10 emphasizing wetland communities and 4 examining stream communities, although in the case of wetlands, the scope of inquiry was typically invertebrates as a food source for birds. Three investigations involved amphibians, and three discussed vertebrates (notably bird nest predators). Seven sources reported on fish, all in the context of intermittent streams.

Of the sources we reviewed on hydrology-ecology relationships and their impacts on fauna or faunal habitat, 51 were from peer-reviewed publications, 5 were agency reports, 4 were management plans ${ }^{5}, 2$ were posters, 1 was a thesis and 1 was a book. Forty-two sources reported on original field work. Nine were literature reviews, or summaries of the literature in management plans. Eleven presented models ${ }^{6}$, and one was an analysis of existing data. The growth of modeling in wetland and stream ecology is especially apparent in more recent sources. It is also a function of several interacting opportunities: better and more available technology, including GIS and desktop computers capable of processing large datasets; the accessibility of large-scale data sets, such as the North American Breeding Bird Surveys, land cover maps from the National Land Cover Dataset, ReGAP and Landfire, and climate data; an increased awareness of the importance of landscape-level factors on PPR biota, especially birds (Naugle et al. 2001; Johnson \& Werner 2010); and the need for integrated conservation and management efforts (Loesch et al. 2011; Niemuth et al. 2011).

\section{Hydrology-ecology relationships: Natural vs. human disturbance}

The extreme variability of wetland and stream habitats in the PPR accounts for much of its diversity. Despite the relative stability of semi-permanently and permanently flooded wetlands, the vacillating conditions associated with seasonal, temporary and ephemeral wetlands may be even more conducive to the maintenance of food webs and waterfowl populations, because they thaw and warm early, while more permanent wetlands are still icecovered (Kantrud et al. 1989). These wetlands may be particularly important for shorebirds as foraging sites during migration (De Leon \& Smith 2009), providing energy reserves essential to

\footnotetext{
${ }^{5}$ Management plans and one book are double counted in the breakdowns, as they covered both abiotic features and faunal habitat.

${ }^{6}$ Some of the sources we count as reporting original field work also presented modeled inferences; these are not included here.
} 
the continued journey (Morrison \& Myers 1989; Colwell \& Oring 1988). North Dakota studies found that shorebirds select shallow, sparsely vegetated sites typically associated with temporary and seasonal flooding (Niemuth et al. 2006). Krapu and colleagues (2006) also found that seasonal wetlands were preferred foraging areas for mallard ducklings, especially in years when some water was available. However, others (Stephens et al. 2005) found that wetland density was negatively correlated with nest success, presumably because predators also tend to occur in greater numbers in wetland-rich environments. Both foraging and rearing success are influenced by invertebrate densities (Anteau and Afton 2008), which in turn depend on the nutrient cycling and sediment oxidation that occurs during dry periods, and the productivity pulse that occurs upon restoration of water levels (Anteau 2011).

Many studies of the impact of water level fluctuations on biodiversity have focused on individual wetlands or wetland types. However, several researchers have emphasized the importance of understanding wetland complexes (Weller et al. 1988, Winter and Rosenberry 1995, Galatowitsch \& Biederman 1998, Weller et al. 1999, Murkin et al. 2000, Naugle et al. 2001, Johnson et al. 2010). Wetland complexes are clusters of wetlands with differing water regimes, often connected by surface water during fluvial periods, or by groundwater during drier years. At the landscape scale, complexes contribute to diversity of vegetation structure and function, and facilitate dispersal of amphibians, and small mammals, as well as foraging birds (Semlitsch 1998, Joyal et al. 2001).

Intermittent and ephemeral streams in Montana's PPR are similar to semi-permanent and seasonal/temporary wetlands in terms of hydroperiod variability. Stagliano (2005) developed an aquatic ecological classification for streams and rivers in the Missouri River drainage of Montana, which includes most of the streams and rivers in Montana's PPR (a small number of PPR streams along the Rocky Mountain Front drain north into the St. Mary's basin). After analyzing over 100,000 fish and macroinvertebrate data records and collecting field surveys to fill data gaps, he delineated ecosystem types based on the presence of specific biological communities and abiotic features of the drainage. Truly ephemeral streams were not included in his classification, as they are generally fishless, with macroinvertebrate populations that are too spatially and temporally variable to permit robust analysis. For the Missouri River drainage of the PPR, he found one consistent intermittent stream type, the Northern Glaciated Intermittent Stream, a $1^{\text {st }}$ to $3^{\text {rd }}$ order stream with an average wetted width of 3 meters, originating in alluvium and sedimentary geology. These are characterized by long pools, usually vegetated, separated from each other by narrow riffle areas that typically dry by early summer, forming isolated pools. Although they may sustain fish populations in wet years, in drought years, they often lose their connectivity to the fish recruitment pools of downstream reaches and become fishless. Reference-condition Northern Glaciated Intermittent Stream communities will have fathead minnows, brook sticklebacks, lake chubs (not as common), brassy minnows 
and northern redbelly dace; with some anthropogenic alteration, the community is codominated by fathead minnows and brook sticklebacks only, and in degraded or non-vegetated streams, only fathead minnows will be found. Because water permanence in these streams is so tenuous, several of their associated fish species are listed as Species of Concern or Potential Species of Concern in Montana (Table 2).

Table 2. Species of concern associated with intermittent streams in Montana's PPR

\begin{tabular}{|l|l|l|}
\hline & \multicolumn{1}{|c|}{ Scientific Name } & \multicolumn{1}{c|}{ Conservation rank } \\
\hline Brassy minnow & Hybognathus hankinsoni & Potential Species of Concern \\
\hline Brook stickleback & Culaea inconstans & Potential Species of Concern \\
\hline $\begin{array}{l}\text { Northern redbelly } \\
\text { dace }\end{array}$ & Chrosomus eos & Species of Concern \\
\hline Pearl dace & Margariscus margarita & Species of Concern \\
\hline
\end{tabular}

In general, the life-history characteristics of prairie stream organisms are highly suited to surviving harsh, disturbance-driven habitats. Stream communities in general have high resilience (Dodds et al. 2004), recovering rapidly from flooding and drying events. Macroinvertebrate communities show high resilience to disturbance, with populations generally recovering to pre-disturbance levels within 1 month, in part because of their high reproductive potential, and in part because of the availability of colonists from nearby water bodies (Hax \& Golladay 2013). However, resilience may be more pronounced in response to flooding than to drying, especially if there is no hyporheic zone providing a refugium (Fritz \& Dodds 2004). Fish and amphibians may also benefit from the seasonal loss of connectivity in intermittent streams, which isolates them from potential predators (Spranza \& Stanley 2000; Meyer et al. 2007).

PPR wetlands and their biotic communities are also well-adapted to natural disturbances other than drought-deluge cycles (Winter and Rosenberry 1998), including fire (Higgens 1984) and grazing by bison and other native ungulates (McNaughton 1986). However, while natural disturbances may have positive impacts on community diversity (DeKeyser et al. 2008), contemporary human disturbances have been negative. Across the PPR, agricultural drainage, excavation, groundwater extraction, and conversion have directly altered individual wetlands and wetland complexes, creating more isolated, and often more permanent wetlands (Krapu et al., 2003, Blann et al. 2009). Agricultural practices in surrounding uplands alter land cover, surface roughness, and soil moisture regimes, thus affecting the hydroperiod of wetlands (van 
der Valk 2005, Voldseth et al. 2007, Voldseth et al. 2009). PPR wetlands are also vulnerable to climate change (Poiani and Johnson 1993, Ojima et al. 1999, Johnson et al. 2005). If, as some models indicate, conditions become warmer during winter, or drier, PPR wetlands can be expected to experience shorter hydroperiods with lower water levels, effectively eliminating all but the wettest wetlands (Clair and Ehrman 1998, Mortsch 1998, Johnson et al. 2005).

Agriculture and urbanization have also led to pollution, hydrologic disturbance and physical modification of streams. These changes can exaggerate effects of flooding and drying, creating conditions outside the range of adaptation for many stream organisms, by disrupting river connectivity, increasing or decreasing sediment loads, decreasing connection to riparian zones, and altering food webs (Dodds et al. 2004). When water extractions lead to lower water levels in intermittent streams, water temperatures may rise to levels that are lethal for some biota, while oxygen levels may drop below what is necessary to sustain fish (Lake 2003). Small dams, water diversions and stock ponds have had the most significant negative impacts on fish communities in intermittent streams (Winston et al. 1991). Anywhere dams occur, even small stock pond earthen dams, reductions in flow alter downstream water temperatures, cause unnatural water level fluctuations, and change sediment and nutrient transport. The spring flows stored behind stock pond dams would otherwise fill pools, and provide brief connectivity between pools to allow recolonization by downstream fish populations (Franssen et al. 2006).

The following pages describe the impact of anthropogenic change on a common suite of wetland functions. Since the mid-1990s, one approach to wetland assessment has emphasized the function of a wetland, rather than its structural features (Smith et al. 1995). While not all wetlands perform all functions at the same level, most wetlands share a common suite of functions, notably 1) flood mitigation; 2) water storage and streamflow maintenance; 3) groundwater recharge; 4) sediment retention; 5) nutrient and chemical cycling; 6) plant community maintenance; 7)maintenance of faunal habitat and biodiversity. Intermittent and ephemeral streams provide many of the same functions as wetlands, acting as islands of moisture in dry uplands, creating habitat for plant and animal species, trapping sediments, sequestering and cycling nutrients, and contributing to the maintenance of perennial streams, rivers and lakes. In addition, these small waterways often provide critical corridors between otherwise isolated ecosystem components. Even when ephemeral streams are dry, their channels can hold enough moisture to support vegetation that is lush in comparison to the surroundings by mid-summer, providing food, shelter and shade. In northern Montana, where intermittent and ephemeral reaches are often interspersed along a channel, small groundwater pools may also provide water for wildlife, rearing areas for waterfowl, and breeding sites for amphibians (Vance 2009). 
Here, impacts on wetland and stream function are summarized in narrative terms. Appendix $D$ lists the numbers of sources describing impacts of individual anthropogenic changes on each wetland function.

\section{Flood mitigation}

In the 1990s, economically catastrophic flooding in the PPR spurred considerable interest in the potential of flood attenuation through wetland restoration. Wetlands store both surface water and overland runoff from precipitation so that they do not enter streams and rivers during a flood event (Kantrud et al. 1989; Murkin 1998; Winter \& Rosenberry 1998; Winter 1989). Several studies reported that drainage of temporary and seasonal wetlands has contributed to increased runoff in the PPR, thus increasing flood frequencies (Cernohous 1979; Moore \& Larson 1979). However, some models indicate that the ability of wetlands to mitigate the impacts of low-frequency, high magnitude events is minimal (Simonovic \& Juliano 2001; Bengtson \& Padmanabhan 1999). Technical investigation on this subject is ongoing, particularly in the Red River Basin of Minnesota, North Dakota, and Manitoba (Philip Gerla, personal communication, March 15, 2013).

As flow-through systems, intermittent and ephemeral streams are not generally considered to have flood mitigation functions. However, alteration of these systems can increase flooding downstream. Agricultural drainage systems often involve channelization of these low-order streams, typically involving dredging and deposition of dredged material in berms. This channelization reduces sinuosity, limits floodplain connectivity, and over time, leads to channel incision, all of which can increase flows to downstream receiving waters (Lenhart et al. 2012).

\section{Water storage}

The PPR has historically cycled between drought and deluge (Donovan \& Grimm 2007). Under natural conditions, wetlands "fill and spill" during years of normal to above-normal spring precipitation, creating surface water connections between basins, with wetlands in the lower basin filling as topographically higher wetlands reach storage capacity. Spring flows, either from snow and ice melt on frozen ground or from rain-on-snow events, are the main source of wetland water. Summer rain infiltrates directly into upland soil where it does little to increase wetland water levels (Woo \& Rowsell 1993). In general, wetland class reflects water storage capacity, with ephemeral wetlands storing the least amount of water, and permanent wetlands storing the most (Gala et al. 2012). However, the sheer number of ephemeral and temporary wetlands means that collectively, their storage capacity is significant (Hayashi et al. 2003). In one South Dakota study, researchers measured the amount of water in small, seasonal, temporary wetlands and semi-permanent wetlands in a 1600-acre study area just after the 
vernal thaw in April, and found them to hold 158.7 acre feet of water, even though they were not full at the time of the study. Extrapolated to the larger Altamont Moraine (249 square miles), this would have meant 15,800 acre feet was being stored in similar wetlands (Hubbard $\&$ Linder 1986). However, water storage functions can be affected by local land use, when roads and culverts in the contributing watershed block runoff (Shaw et al. 2012). Agricultural impacts on water storage vary. For example, increased sedimentation from agriculture can fill shallow basins and reduce storage capacity (Detenbeck et al. 2002; Martin 1985). Conversion of native grasslands to agriculture can also result in higher runoff rates during spring rains because of less surface water interception by native grasses (Voldseth et al. 2009), unless stubble management practices are implemented (Granger et al. 1984; Conly \& van der Kamp 2001). Direct draining and ditching of wetlands is probably the most significant impact to wetland water storage functions (Brunet 2011; Hubbard \& Linder 1986; Bengtson \& Padmanabhan 1999; Moore \& Larson 1979; Winter 1989; van der Kamp \& Hayashi 1998).

\section{Groundwater recharge}

Snow accumulation is highly uneven on upland slopes, creating spatial variation in infiltration and overland flow, and summer rainfall infiltrates only the top layers of soil. Consequently, uplands play a limited role in groundwater recharge. In the PPR, most groundwater recharge occurs under wetland inundation zones (Woo \& Rowsell 1993), and indeed, wetlands are the main source of recharge to prairie aquifers (van der Kamp \& Hayashi 1998). In deluge periods, when high water levels push vegetation to wetland margins, groundwater recharge is greater than in drought periods, when evapotranspiration rates are higher (Winter \& Rosenberry 1998). In general, more water is lost to the atmosphere from plants rather than through open water evaporation (Labaugh et al. 1998). Consequently, decreases in surface or groundwater inflow to more permanent wetlands, to the extent they promote vegetation establishment, will reduce groundwater recharge functions. However, even small seasonal wetlands contribute to maintenance of groundwater early in the season. Hubbard and Linder (1986) estimated that $12 \%$ of the water in small wetlands in their 1600 -acre study area generated groundwater that flowed beyond the wetland. That amount, they concluded, would be sufficient to spread 1.4 inches of irrigation water across 160 acres of crops, or water 1,700 cattle for a year.

Locally, draining and ditching can affect yields in shallow wells, while regional aquifers will still be replenished if the diverted water is captured in reservoirs and ponds (van der Kamp \& Hayashi 1998). Factors that impact water storage will also affect groundwater recharge. For example, planting permanent grass for nesting cover increases infiltration in uplands through macropores, while trapping snow and surface water that would otherwise collect in wetland basins; this reduces the water available for groundwater recharge (van der Kamp et al. 2003). Upland grazing can be managed to reduce upland plant leaf area and ground cover, and thus 
increase water levels and hydroperiod, if it can be managed to minimize soil compaction impacts and surface litter loss (Voldseth et al. 2007).

Intermittent streams are more commonly groundwater discharge sites than recharge sites. However, one study found that damming of intermittent streams in headwater reaches can have positive effects on riparian vegetation downstream of the dam, by expanding hyporheic connectivity in the riparian zone; groundwater recharge was also noted below the dam (Duke et al. 2007). Although this was a Texas study, these patterns are visible across Montana's PPR, where stock ponds and other impoundments may have lush riparian zones in the immediate downstream area. However, the effect disappears a short distance downstream, and pre-dam aquatic and riparian habitat is overtaken by encroaching upland vegetation, and often, invasive plant species.

\section{Sediment retention}

Sediment retention is generally considered to be a water quality function of wetlands, capturing soil-bound nutrients and pesticides, and trapping soil particles that would otherwise enter streams and rivers. In the highly cultivated parts of the PPR, wetlands typically receive excessive sediment. Consequently, most of the sources we reviewed focused on the negative aspects of sediment retention, e.g., limited water storage capacity (Guntenspergen et al. 2002), impacts on seed emergence (Jurik et al. 1994), and invertebrate egg banks (Gleason \& Euliss 1998; Euliss \& Mushet 1999). In deeper wetlands with longer hydroperiods, sedimentation may also increase turbidity, thus limiting light penetration into the water column, which affects macrophyte production (Zimmer et al. 2003) and alters food webs(McCabe \& O'Brien 2013). Both soil tillage and heavy grazing are causes of sedimentation (Dieter 1990) although practices such as conservation tillage can reduce some of the impacts (Freeland \& Richardson 1997).

In their natural state, neither intermittent nor ephemeral streams are a major source of sediment for downstream waters. However, when these streams are excavated, widened, or used for drainage, sediment transport increases, especially if the alterations are accompanied by crop tillage or other soil-disturbing activities in the upstream drainage area (Lenhart et al. 2012; Schilling et al. 2011) or by heavy grazing near the stream (van der Kamp et al. 2013; Rosso \& Fernández Cirelli 2013).

\section{Nutrient and chemical cycling}

Nutrient and chemical cycling is also a wetland water quality function when considered in terms of protecting streams, lakes and rivers. However, wetlands themselves can become nutrient impaired (Silver \& Vamosi 2012; North 2000). The biogeochemistry of wetlands is complex. Hydroperiod determines the duration of oxic and anoxic soil conditions, which drive nutrient 
and chemical transformation, while surrounding land uses and chemical composition of contributing flows determine the amount of influx (Brunet 2011; Guntenspergen et al. 2002). In the case of nitrogen, hydroperiod will determine both organic matter decomposition and microbial nitrogen mineralization, which regulates the release of ammonium to soils, and its potential for plant uptake. The alternating wet/dry cycles characteristic of most seasonal and temporary wetlands promote nitrification and denitrification. If hydroperiod in a wetland is shortened through consolidation drainage, denitrification may slow. Similarly, when flowthrough wetlands are modified into closed systems, nutrients and salts are often concentrated.

Changes to nutrient cycling within a wetland may manifest in different ways. For example, when land use or hydrologic alteration cause excess nitrogen inputs, plant biomass may increase. In turn, this can produce higher litter loads that depress germination of some seeds, impede survival of seedlings (Neill 1995), and create anoxic conditions (Goldsborough \& Crumpton 1998; Zeng et al. 2011). In cultivated watersheds, where the flux of inorganic sediments into wetlands can be twice as high as in native grassland watersheds, phosphorus levels will also increase (Martin \& Hartman 1987). High nitrogen and phosphorus levels in wetlands often promote the growth of cattails (Neely et al. 1989), which lower dissolved oxygen in wetland waters while increasing oxygen flow to soils (Rose \& Crumpton 1996). This altered plant community composition increases sediment capture, ultimately causing filling of the wetland, and a loss of functions dependent on water storage capacity.

In the past decade, there has been considerable interest in carbon sequestration potential in PPR wetlands. In one study, researchers concluded that restoring all farmed wetlands in the region could sequester as much as 378 million metric tons of organic carbon over a 10-year period, offsetting $2.4 \%$ of the fossil emissions reported for North America in 2002 (Euliss et al. 2006). This study noted that carbon storage was highest in semi-permanent wetlands, suggesting that hydrologic alterations which reduce inundation periods or areal extent of a wetland would have negative impacts on carbon storage.

Streams in the glaciated prairie typically lack woody debris, which is an important component in nutrient cycling insofar as it traps organic matter during flow events (Quist \& Guy 2001). However, even grassy streambeds will trap and cycle nutrients. When intermittent and ephemeral stream channels are dredged to provide drainage, replacement of grassy streambeds by bare soil results in a loss of nutrient cycling capacity (Brunet \& Westbrook 2012; Dodds \& Oakes 2006).

\section{Plant community maintenance}

Native plant communities in the PPR are uniquely adapted to the varying hydroperiods caused by climatic oscillations. Hydrology affects biochemistry, and hydrology and biochemistry 
together determine plant community dynamics. Depending on the source and residence time of water, wetland salinity will vary (Labaugh et al. 1998). Recharge wetlands, driven by precipitation, are the least saline, while wetlands with significant groundwater discharge can be highly saline (Kantrud et al. 1989). Plant communities vary with hydroperiod fluctuations under normal conditions. For example, in a semi-permanent wetland with a ring of emergent vegetation under "normal" water conditions, drought will result in more vegetation moving into the center of the wetland, while under deluge conditions, all vegetation may be drowned out, with the wetland becoming an open water lake (Winter \& Rosenberry 1998). However, when seasonal or semi-permanent wetlands are excavated to increase residence time of water, emergent vegetation and the macroinvertebrate communities that depend on it may be lost permanently (Euliss \& Mushet 2004). Changes in vegetation create feedback loops, affecting physiochemical properties of wetlands. Wetlands with emergent macrophytes will have lower light levels, higher nutrient levels, higher dissolved methane levels, higher particulate organic matter, lower temperatures with less diurnal variation, and lower oxygen levels than open water(Rose \& Crumpton 1996)

Plant communities in wetlands also change when upland land uses alter hydroperiod (Voldseth et al. 2007), sediment input (Jurik et al. 1994; Dieter 1990) and nutrient loads (Neely et al. 1989). Wetlands surrounded by cropland exhibit less diversity and species richness than those surrounded by native grasses, and have a greater number of invasive species (Guntenspergen et al. 2002). Just as plant communities shift with hydrologic change, hydrology can change when land use alters plant communities. For example, researchers in Saskatchewan examined a 30-year record of water levels in wetland with a 950 acre basin. For 12 years, all the land surrounding the wetlands was in dryland cultivation. Over a three year period, a third of the land was converted to a permanent cover of smooth brome and alfalfa to provide habitat for nesting ducks. Within four years of the conversion, the wetlands surrounded by permanent grass dried out, while water levels remained normal in the wetlands surrounded by dryland crops (van der Kamp et al. 1999).

Hydrologic alteration can also facilitate the spread of exotic and invasive species. Saltcedar (Tamarix spp.) establishes in areas where water tables have been lowered, or along wetland margins in areas that have been overgrazed, burned, or otherwise cleared of vegetation (Ohrtman et al. 2011). Because it is a heavy water user, and increases evapotranspiration from wet sites, saltcedar has the potential to further modify hydroperiod in temporary wetlands (Sexton et al. 2006). Salt cedar is also becoming an increasingly common invader in Great Plains streams where groundwater levels are being lowered by pumping, displacing riparian species that depend on high water tables. Its deep roots, prolonged seed dispersal period, drought and salinity tolerance allow it to thrive in intermittent and ephemeral streams, or perennial streams that have lost permanence following water diversion (Stromberg et al. 2008). Although it is not 
yet widely naturalized north of the Missouri River, a combination of hybridization, cold adaptation and warming temperatures threaten to expand its range into the Montana PPR (Lesica \& Miles 2001)

\section{Faunal habitat and biodiversity}

All of the sources in the literature review supported the conceptual model's hypothesis that changes in inflow to, or outflow from, a wetland, will alter hydroperiod, which in turn will affect faunal habitat, either by decreasing the number and size of preferred breeding and foraging sites, making them less suitable, or by changing interspecific relations.

There is no single "best" hydroperiod for PPR fauna; rather, individual species and guilds ${ }^{7}$ select for wetlands whose hydroperiod best suits their needs (Figure 17). For example, Murkin et al. (1997) manipulated water levels in experimental marshes to associate bird presence with habitat types. Over the 10-year study period, they found that different species selected different flooding regimes: yellow-headed blackbirds preferred shallow, open water with emergent vegetation; red-winged blackbirds selected densely-vegetated shallow margins of semi-permanent wetlands; and coots were consistently found in deep water with interspersed vegetation patches. Most dabbling ducks selected similar habitat (open water with interspersed vegetation patches), while diving ducks such as ruddy ducks, canvasbacks and lesser scaup gravitated to deeper, open water.

Overall, relationships between ducks and hydrologic alteration are complex, and hydrologic modifications intended to expand habitat may reduce or impair it. One study reported that artificial flooding of a wetland complex, rather than improve deepwater habitat for scaup, resulted in an increase in fish, which in turn decreased the amphipod population preferred by scaup as a high-energy food source (Strand et al. 2007). A case study on Benton Lake Wildlife Refuge in Montana detailed the impacts associated with artificial flooding of seasonal wetlands to provide recreational use. Diversion of irrigation return flows and agriculturally-impacted waters from local creeks has led to elevated and increasing selenium contamination; decreasing diversity in vegetation; increased invasive weeds; declining wetland and bird productivity; and avian botulism outbreaks (Heitmeyer et al. 2009).

Both natural and anthropogenic decreases in the amount of available wetland habitat can affect bird populations. Spring breeding surveys indicate that populations of all common duck species (northern pintail, mallard, blue-winged teal, northern shoveler, gadwall, green-winged

\footnotetext{
${ }^{7}$ Appendix C, which lists the species used in our literature search, also includes guild assignments for each, courtesy of Sean Fields of the US Fish and Wildlife Service.
} 

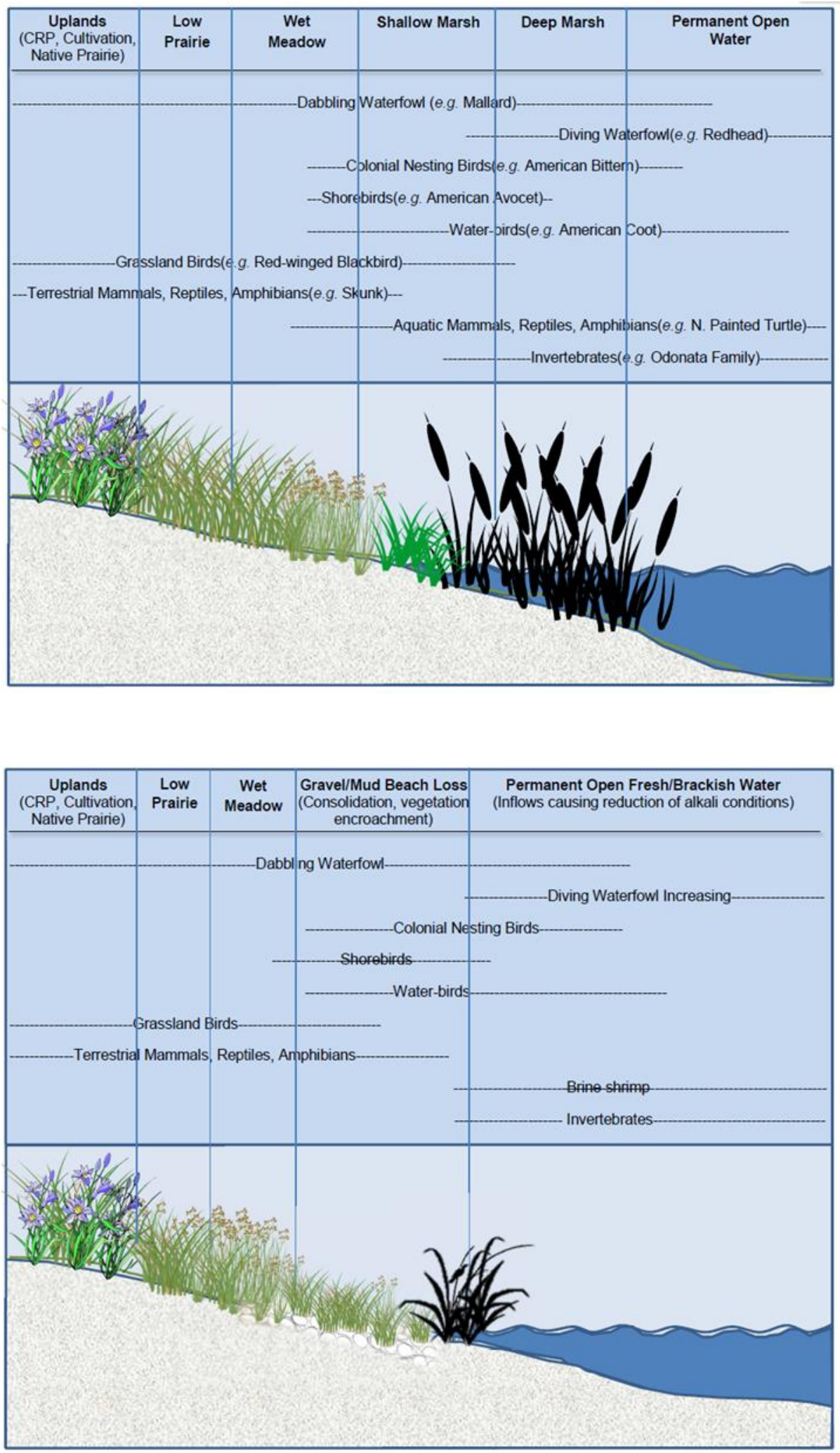

Figure 17. Waterfowl use of inundation zones in freshwater (top) and brackish (bottom) wetlands in the PPR. 
teal, American wigeon, canvasback, red head, and scaup) rise and fall in concert, and correlate strongly to the number of observed seasonal, semi-permanent or permanent wetlands (Drever 2006). Correlations have also been noted between numbers of wetlands and pied-billed grebe, black tern, American bittern, sora, and American coot ( Niemuth \& Solberg 2003). It has been suggested that one of the reasons behind the correlation is that conditions favoring wetland abundance (i.e., unusually wet conditions the previous year, or heavy winter snow and/or spring precipitation) also shift the ratio of temporary to seasonal wetlands in that year (Forcey et al. 2007). In extremely wet years, otherwise temporary or seasonal wetlands may be absorbed into larger, semi-permanent basins (Kahara et al. 2009). However, while wetter conditions may favor diving and dabbling ducks, they may disadvantage shorebirds.

Several sources reported on the importance of seasonal and temporary wetlands for shorebird foraging and waterfowl nesting. Steen and Powell (2012) found that, at the landscape level, only the density of small seasonal wetlands within a 2-km radius was a predictor of black tern breeding and foraging. Walker and colleagues (2013) predicted, from field surveys, that bluewinged teal, gadwall, mallard, northern pintail, and northern shoveler will be most abundant in landscapes with small-to-medium size temporary or seasonal wetlands, with the highest site occupancy occurring in areas with the most overall wetland area. Also using a model based on results of field surveys, Reynolds and colleagues (2006) found that populations of the same five species would decrease by as much as $37 \%$ if small seasonal wetlands in private ownership in North and South Dakota were drained. These conclusions are supported by field survey findings that mallard ducklings were 1.5 times more likely to die when the percentage of seasonal basins containing water was $<18 \%$ than when the percentage was $>40 \%$ (Krapu et al. 2003). Conversely, mallard duckling survival is highest when there are seasonal wetlands with open water and a fringe of emergent vegetation within $1 / 2$ kilometer of a nest (Bloom et al. 2012). Several researchers have also noted the importance of seasonal and temporary wetlands to migrating and resident shorebirds (Skagen et al. 2008). De Leon and Smith (2013) identified seasonal wetlands a critical foraging ground for long-billed dowitchers, stilt, semipalmated and least sandpipers, and American avocet. The availability of seasonal wetlands with water also determines the frequency and length that some birds, notably mallards, will stop during migration (Krementz et al. 2011). Niemuth and colleagues (2006) surveyed 1,181 temporary and seasonal wetlands surrounded by cropped fields in North Dakota over a 10week period in spring of 2001 , observing a total of 4,050 shorebirds of 25 species. Data analysis indicated that shorebirds selected temporary wetlands with shallow water, little emergent vegetation, a large perimeter (i.e., a meandering shoreline), and other wetlands nearby.

The importance of small, temporary and seasonal wetlands to birds is due in large part to the food sources they provide. Small, shallow wetlands warm earlier in the season than larger, more permanent wetland, and provide an abundant source of invertebrate protein for 
shorebirds and dabbling ducks during the early season (Swanson et al. 1974). When these wetlands are drained to consolidate water in lower, semi-permanent or permanent wetlands, vegetation composition and macroinvertebrate communities change (Anteau 2011), to the detriment of foraging shorebirds. Artificial management of water levels can also affect invertebrate species density and abundance in more permanent wetlands. Anthropogenic manipulation of water levels that extend inundation, or increased sedimentation from surrounding uplands, may promote the growth of aggressive macrophytes such as Typha and Phalaris; these, in turn, can lead to increased amounts of litter, negatively affecting macroinvertebrate abundance and causing shifts in trophic structure (Lavergne \& Molofsky 2004; Werner \& Zedler 2002; Christensen \& Crumpton 2010; Mabry \& Dettman 2010).

Three sources reported some positive impacts of hydroperiod alteration. One source, reporting on a GIS analysis, identified more upland nesting opportunities for mallards and pintails when ephemeral wetlands were converted to cropland (Drever 2006). One after-impact study, which contradicted many other studies, found higher brood survival for upland nesting ducks in areas of lower wetland density (Stephens et al. 2005). A third study found that white-faced ibis, which are not native to the PPR, have been establishing there since the 1970s; the authors surmise it is due to increased numbers of permanent and semi-permanent ponds being created by consolidation drainage, and the associated increase in cattail-dominated vegetation (Shaffer et al. 2007).

Although macroinvertebrate community composition has been investigated as a potential bioindicator of wetland condition (Apfelbeck 1999; Hentges 2008; Tangen et al. 2003) and as a means of identifying relict wetlands that have been subjected to cultivation (Euliss et al. 2001), macroinvertebrates are rarely used to track specific effects of hydrologic alteration in wetlands. However, stream ecologists have examined the relationship between flow alteration and macroivertebrates, focusing on resistance and resiliency. Under natural conditions, macroinvertebrates will recolonize stream habitats within a week of interrupted flows being resumed (for example, when rains follow a drought period) or after an intense flood, either drifting downstream from upstream pools and/or subsurface water, crawling upstream, or hatching from eggs deposited by aerial adults (Dodds et al. 2004). By contrast, anthropogenic alterations that do not mimic wet-dry cycles may alter communities permanently, especially if water is diverted from springs or seeps that provide refuge during dry periods (Fritz \& Dodds 2004).

Amphibian use of PPR wetlands has received relatively little attention, even though three of the four species associated with PPR wetlands in Montana are listed as species of concern (northern leopard frog, Great Plains toad, and Plains spadefoot), primarily as a result of habitat loss and fragmentation. In an lowa study of eight amphibian species, researchers found that all 
species were least likely to be found in seasonal wetlands in farmed areas, and most likely to be found in seasonal wetlands embedded in native grasslands (Balas et al. 2012). They theorized that this was a function of wetlands in native grasslands having longer and more stable hydroperiods than farmed wetlands, where sedimentation often fills wetlands, and where crops extract water from soils. This theory is supported by a study of amphibian populations in Theodore Roosevelt National Park in North Dakota, outside the PPR, where there has been no grassland conversion, and where populations of boreal chorus frog, Woodhouse's toad, northern leopard frog, plains spadefoot and Great Plains toad have remained stable since the 1920s (Hossack \& Stephen 2002). Direct alterations of hydroperiod have also been found to affect amphibian presence and condition. For example, Euliss \& Mushet (2004) carried out a control-vs-impact study of excavated, semi-permanent wetlands compared to seasonal wetlands, reporting deeper and more permanent water favored tiger salamanders over boreal chorus frogs and northern leopard frogs, which did not reproduce in the salamanders' presence. Benoy (2008) also found that tiger salamander presence increased when water permanence increased in wetlands, mimicking the effects of planktivorous fish in changes to the wetland food web.

Because the project emphasized pothole wetlands, the literature search yielded only passing references to fish, which are typically only present in larger permanent wetlands with surface water inflows or outflows, or as introduced species in ponds. The literature on prairie streams also contained little mention of fish. Because of the harsh and fluctuating conditions that aquatic organisms face in intermittent streams, where hypoxia and hyperthermia are common, only a handful of fish species are found, and intermittent prairie streams will often be fishless (Smale \& Rabeni 1995). When fish assemblages do occur, impacts of hydrologic disturbance depend on the availability and proximity of refugia (Franssen et al. 2006) and the duration of the disturbance (Dodds et al. 2004). Permanent water diversions will lead to loss of fish populations (Stagliano 2005). Similarly, connecting intermittent streams to more permanent water bodies through dredging or consolidation drainage may introduce predators that decimate the small fish characteristic of intermittent streams (Spranza \& Stanley 2000).

Research reports on mammal use of PPR wetlands and intermittent/ephemeral streams are limited, except when linked to nest predation (Brook et al. 2008; Drever et al. 2004). However, a number of small mammals use grasslands in and around PPR wetlands, including skunks (Larivière \& Messier 2000), meadow voles, shrews, ground squirrels, deer mice and meadow jumping mice (Wiewel et al. 2007), and native ungulates typically bed down in the cooler, taller grass found near stream channels on hot summer days. 


\section{Discussion}

As has been observed in other flow-ecology studies (McManamay et al. 2011), the literature review conducted for this project demonstrates that ecological responses to natural changes in wetland hydrology are variable, depending on the direction of change and the species, guild or function affected. Droughts generally lead to decreases in avian, macroinvertebrate and fish abundance, although depending on the extent and duration of the drought, consequences may be expressed more as changes in community structure. Flood cycles, in contrast, promote both greater abundance and changes in community structure, in part because flooding increases available habitat by increasing the areal extent of wetland and stream habitats.

However, ecological responses to anthropogenic alteration are almost entirely negative. This difference reflects the duration of natural vs. anthropogenic change. Natural hydroperiods of wetlands and prairie streams vary spatially and temporally, with flood and drought cycles altering. In contrast, human manipulations of flood frequency, duration or extent tend to be permanent, as are the changes in wetland function that they induce. For example, drained wetlands are effectively trapped in a permanent drought condition; similarly, shallow flowthrough wetlands that are excavated and impounded will be flooded indefinitely.

Most of the studies that discuss the source of anthropogenic change focus on agriculture (Appendix D), primarily because that has been the most widespread human land use activity in the PPR. However, agriculture per se, while implicated in the change of surface runoff patterns and increases in sedimentation, is not the principal cause of all hydrologic change. Instead, it is the manipulations of hydrological conditions that often accompany agriculture: water pumping and diversion; tilling of shallow wetlands; excavation of wetlands to provide more permanent water storage; various forms of draining; dredging and channelization of intermittent and ephemeral streams; and impoundments of seasonal stream flows by dams or culverts. Any kind of development that alters surface permeability or changes flow patterns are likely to have similar impacts on functions, processes and biota, including construction of infrastructure for energy extraction and development, groundwater pumping for residential or industrial use, and impoundments for recreational use. However, these effects have not yet been extensively studied; this is an area requiring further research.

Region-wide surveys of wetlands (e.g., Niemuth et al. 2011) and models predicting climate change impacts (e.g., Naugle et al. 2001; Johnson et al. 2005) were the only sources in our review that quantified changes in wetland extent, class and distribution based on hydrologic inputs. However, precipitation was the only factor that could be quantified. Unlike rivers, which can be instrumented to link specific flows to specific responses, wetlands have more diffuse inputs, which vary on both spatial and temporal scales. Consequently, we do not find good support for specific precautionary limits on hydrologic alteration, beyond those that can 
be expressed in terms of their effects (e.g., loss of permanence, loss of hydrophytic vegetation, changes in areal extent of a wetland, etc.).

The review raises several questions of scale. As noted earlier, while individual wetlands were once the main focus of research, in recent years attention has shifted to wetland complexes (Johnson \& Werner 2010; Shaw et al. 2012). Individual wetlands may not be the appropriate units for evaluating, or regulating, hydrologic alteration, except in the case where the wetland is so large or so unique (e.g., certain alkaline lakes) that it is the only habitat feature of its kind in an area. Instead, it may be better to emphasize specific wetland landscape profiles as a target. In areas where human disturbance is minimal, wetland abundance, diversity of wetland types, and characteristic wetland size are linked to such landscape-level factors as geomorphology, basin hydrology, and regional or local climate (Johnson 2005). Consequently, similar landscapes can be expected to have similar wetland "profiles." These profiles in turn establish which wetland functions are associated with a particular region (e.g., subbasin, watershed, subwatershed), and maintenance (or restoration) of that profile can be targeted. This approach has been adopted as a wetland assessment tool in Montana (Vance et al. 2006; McIntyre et al. 2011; Newlon 2012) and Colorado (Lemly \& Gilligan 2012). Once a "natural" profile is established, it would be possible to set thresholds of acceptable (and unacceptable) change, e.g., no more than $10 \%$ loss of semi-permanent wetlands. Such targets could frame precautionary limits on hydrologic modification. Wetland landscape profiling is similar to the "thunderstorm maps" (Loesch et al. 2011) used to identify duck habitat conservation targets, but emphasizes wetlands rather than wetland-dependent species.

A final caveat about the results of the literature review is in order: with the exception of agency reports and unpublished documents, very few studies and research reports examine wetlands or intermittent and ephemeral streams in Montana. Although impacts of hydrologic alteration on waterbirds can be extrapolated from adjacent states and provinces, more research on faunal use of seasonal and temporary wetlands in arid areas may be warranted. Because it lies mostly west of the Missouri Coteau, Montana's prairie wetlands differ from those in the eastern parts of the PPR, with less wetland and stream density, fewer permanent wetlands and perennial streams, distinct climate patterns, and a different geologic profile. 


\section{References}

Anteau, M. J., and A. D. Afton. 2008. Amphipod densities and indices of wetland quality across the upper-Midwest, USA. Wetlands, 28:184-196.

Anteau, M.J. 2012. Do interactions of land use and climate affect productivity of waterbirds and prairie pothole wetlands? Wetlands 32(1): 1-9.

Apfelbeck, R.S. 1999. Development of biocriteria for wetlands in Montana. Available at: http://deq.mt.gov/wqinfo/Wetlands/paper5j.mcpx [Accessed April 8, 2013].

Armstrong, A. , R. Stedman, and J. Bishop. 2012. What's a stream without water? Disproportionality in headwater regions impacting water quality. Environmental Management 50(5): 849-60.

Balas, C.J., N.H. Euliss, and D.M. Mushet. 2012. Influence of conservation programs on amphibians using seasonal wetlands in the Prairie Pothole Region. Wetlands 32(2): 333345.

Bengtson, M.L. \& G. Padmanabhan. 1999. Hydrologic model for assessing the influence of wetlands on flood hydrographs in the Red River basin. Report submitted to International Joint Commission Red River Task Force, Minnesota Department of Natural Resources, Division of Waters, Fargo, North Dakota.

Benoy, G.A., 2008. Tiger salamanders in prairie potholes: a "fish in amphibian's garments?" Wetlands, 28(2): 464-472.

Blann, K.L., J. Anderson, G. Sands, and B. Vondracek. 2009. Effects of agricultural drainage on aquatic ecosystems: A review. Critical Reviews in Environmental Science and Technology, 39(11): 909-1001.

Bloom, P.M., R.G. Clark, D. Howerter, and L.M. Armstrong. 2012. Landscape-level correlates of mallard duckling survival: implications for conservation programs. The Journal of Wildlife Management, 76(4): 813-823.

Brook, R.W. M. Pasitschniak-Arts, D. Howerter, and F. Messier. 2008. Influence of rodent abundance on nesting success of prairie waterfowl. Canadian Journal of Zoology, 86(6): 497-506.

Brunet, N.N. and C.J. Westbrook. 2012. Wetland drainage in the Canadian prairies: nutrient, salt and bacteria characteristics. Agriculture, Ecosystems \& Environment, 146(1): 1-12.

Brunet, N.N. 2011. Prairie pothole drainage and water quality. Masters thesis. University of Sakatchewan, Saskatoon, SK. 87 pp. 
Cernohous, L. 1979. The role of wetlands in providing flood control benefits. U.S. Fish and Wildlife Service. Bismarck, North Dakota.

Christensen, J.R. and W.G. Crumpton. 2010. Wetland invertebrate community responses to varying emergent litter in a prairie pothole emergent marsh. Wetlands, 30(6): 1031-1043.

Colwell, M.A. and L.W. Oring. 1988. Habitat use by breeding and migrating shorebirds in southcentral Saskatchewan. Wilson Bulletin, 100: 554-556.

Conly, F. M. and G. Van der Kamp. 2001. Monitoring the hydrology of Canadian prairie wetlands to detect the effects of climate change and land use changes. Environmental Monitoring and Assessment, 67(1-2): 195-215.

Cowardin, L.M, V. Carter, F.C. Golet, and E.T. LaRoe. 1979. Classification of wetlands and deepwater habitats of the United States, Washington, D.C.: U.S. Department of the Interior, Fish and Wildlife Service. 131 pp.

DeKeyser, E.S., M. Biondini, D. Kirby, and C. Hargiss. 2008. Low prairie plant communities as a function of disturbance: physical parameters. Ecological Indicators 9:296-306.

De Leon, M.T. and L.M. Smith. 2009. Behavior of migrating shorebirds at North Dakota prairie potholes. The Condor, 101(3): 645-654.

DePhilip, M. and T. Moberg. 2010. Ecosystem flow recommendations for the Susquehanna River Basin. The Nature Conservancy, Harrisburg, PA. Available at: http://www.nature.org/media/pa/tnc-final-susquehanna-river-ecosystem-flows-studyreport.pdf.

Detenbeck, N.E., C.M. Elonen, D.L. Taylor, A.M. Cotter, A. Frank, and W.D. Sanville. 2002. Effects of agricultural activities and best management practices on water quality of seasonal prairie pothole wetlands. Wetlands Ecology and Management 10: 335-354.

Dieter, C.D. 1990. The importance of emergent vegetation in reducing sediment resuspension in wetlands. Journal of Freshwater Ecology, 5(4): 467-473.

Dodds, W.K., K. Gido, M.R. Whiles, K.M. Fritz, and W.J. Matthews. 2004. Life on the edge: the ecology of great plains prairie streams. BioScience, 54(3): 205-216.

Dodds, W.K. and R.M. Oakes. 2006. Controls on nutrients across a prairie stream watershed: land use and riparian cover effects. Environmental Management, 37(5): 634-646.

Donovan, J.J. and E.C. Grimm. 2007. Episodic struvite deposits in a Northern Great Pla ins flyway lake: indicators of mid-Holocene drought? The Holocene, 17(8): 1155-1169. 
Drever, M.C., A. Wins-Purdy, T.D. Nudds, and R.G. Clark. 2004. Decline of duck nest success revisited: relationships with predators and wetlands in dynamic prairie environments. The Auk, 12(2): 497-508.

Drever, M.C. 2006. Spatial synchrony of prairie ducks: roles of wetland abundance, distance, and agricultural cover. Oecologia, 147(4): 725-733.

Duke, J.R., J.D. White, P.M. Allen, and R.S. Muttiah. 2007. Riparian influence on hyporheic-zone formation downstream of a small dam in the Blackland Prairie region of Texas. Hydrological Processes, 150: 141-150.

Euliss, N.H., D.M. Mushet, and D.H. Johnson. 2001. Use of macroinvertebrates to identify cultivated wetlands in the prairie pothole region. Wetlands, 21(2): 223-231.

Euliss, N.H., R.A. Gleason, A. Olness, R.L. McDougal, H.R. Murkin, R.D. Robarts, R.A. Bourbonniere, and B.G. Warner. 2006. North American prairie wetlands are important non-forested land-based carbon storage sites. The Science of the Total Environment, 361(13): 179-88.

Euliss, N.H. and D.M. Mushet. 2004. Impacts of water development on aquatic macroinvertebrates, amphibians, and plants in wetlands of a semi-arid landscape. Aquatic Ecosystem Health and Management, 7(1): 73-84.

Euliss, N.H. and D.M. Mushet. 1999. Influence of agriculture on aquatic invertebrate communities of temporary wetlands in the Prairie Pothole Region of North Dakota, USA. Wetlands, 19(3): 578-583.

Forcey, G.M., G.M. Linz, W.E. Thogmartin, and W.J. Bleier. 2007. Influence of land use and climate on wetland breeding birds in the Prairie Pothole Region of Canada. Canadian Journal of Zoology, 85(3): 421-436.

Franssen, N.R., K.B. Gido, C.S. Guy, J.A. Tripe, S.J. Shrank, T.R. Strakosh, K.N. Bertra nd, C.M. Franssen, K.L. Pitts, C.P. Paukert. 2006. Effects of floods on fish assemblages in an intermittent prairie stream. Freshwater Biology, 51(11): 2072-2086.

Freeland, J.A. and J.L. Richardson. 1997. Soils and sediments as indicators of agricultural impacts on northern prairie wetlands. In Peterson, S.A., L. Carpenter, G. Guntenspergen, and L.M. Cowardin, eds. Pilot test of wetland condition indicators in the prairie pothole region of the United States. EPA/620/R-97/002. Corvallis, OR: U.S. Environmental Protection Agency, Office of Research and Development, National Health and Environmental Effects Research Laboratory, Western Ecology Division, pp. 119-144.

Fritz, K.M. and W.K. Dodds. 2004. Resistance and resilience of macroinvertebrate assemblages to drying and flood in a tallgrass prairie stream system. Hydrobiologia, 527(1): 99-112. 
Gala, T.S., R.J. Trueman, and S. Carlyle. 2012. Soil hydrodynamics and controls in prairie potholes of central Canada. Area, 44(3): 305-316.

Galatowitsch, S.M., L.A. Biederman. 1998. Vegetation and seedbank composition of temporarily flooded Carex meadows and implications for restoration. International Journal of Ecology and Environmental Sciences, 24: 253-270.

Gilbert, M.C., P.M. Whited, E.J. Clairain and R.D. Smith 2006. A Regional Guidebook for Applying the Hydrogeomorphic Approach to Assessing Wetland Functions of Prairie Potholes, ERDC/EL TR-06-5 U.S. Army Engineer Research and Development Center, Vicksburg, MS.

Gleason, R.A., B.A. Tangen, B.A. Browne, and N.H. Euliss. 2009. Greenhouse gas flux from cropland and restored wetlands in the Prairie Pothole Region. Soil Biology and Biochemistry, 41(12): 2501-2507.

Gleason, R.A. and N.H. Euliss. 1998. Sedimentation of prairie wetlands. Great Plains Research, 8: 97-112.

Goldsborough, L.G. and W.G. Crumpton. 1998. Distribution and environmental fate of pesticides in prairie wetlands. Great Plains Research, 8: 73-95.

Granger, R.J., D.M. Gray, and G.E. Dyck. 1984. Snowmelt infiltration to frozen prairie soils. Canadian Journal of Earth Sciences, 21(6): 669-677.

Greet, J., J.A. Webb, R.D. Cousens. 2011. The importance of seasonal flow timing for riparian vegetation dynamics: a systematic review using causal criteria analysis. Freshwater Biology 56(7):1231-1247.

Guntenspergen, G.R., S.A. Peterson, S.G. Leibowitz, and L.M. Cowardin. 2002. Indicators of wetland condition for the Prairie Pothole Region of the United States. Environmental Monitoring and Assessment, 78(3): 229-252.

Hargiss, C.L.M., E.S. DeKeyser, D.R. Kirby, and M.J. Ell. 2008. Regional Assessment of wetland plant communities using the index of plant community integrity. Ecological indicators, 8(3): 303-307.

Hax, C.L. and S.W. Golladay. 2013. Flow disturbance of macroinvertebrates inhabiting sediments and woody debris in a prairie stream. American Midland Naturalist, 139(2): 210-223.

Hayashi, M., G. Van der Kamp, and R. Schmidt. 2003. Focused infiltration of snowmelt water in partially frozen soil under small depressions. Journal of Hydrology, 270(3-4): 214-229. 
Heidel, B., S.V. Cooper, and C. Jean. 2000. Plant species of special concern and plant associations of Sheridan County, Montana. Report to the US Fish and Wildlife Service., Montana Natural Heritage Program, Helena, MT. 93 pp.

Heitmeyer, M.E., V.L. Fields, M.J. Artman, and L.H. Fredrickson. 2009. An evaluation of ecosystem restoration and management options for Benton Lake National Wildlife Refuge. Prepared for U.S. Fish and Wildlife Service, Region 6,Denver, CO. Greenbrier Wetland Services Publication 09-01. Blue Heron Conservation Design and Printing, LLC, Bloomfield, MO.

Hentges, V.A. 2008. Macroinvertebrate community characteristics and related environmental features in prairie pothole wetlands of lowa. Masters thesis. University of lowa. 124 pp.

Higgens, K.F. 1984. Lightning fires in North Dakota grasslands and in pine-savanna lands of South Dakota and Montana. Journal of Range Management, 37: 100-105.

Hossack, B.R. and P. Stephen. 2002. Lack of significant changes in the herpetofauna of Theodore Roosevelt National Park, North Dakota, since the 1920s. American Midland Naturalist, 154: 423-432.

Hubbard, D.E. and R.L. Linder. 1986. Spring runoff retention in prairie pothole wetlands. Journal of Soil and Water Conservation, 41(2): 122-125.

Johnson, B. 2005. Hydrogeomorphic wetland profiling: an approach to landscape and cumulative impacts analysis. EPA/620/R05/001, Washington, DC.

Johnson, W.C., B.V. Millett, T. Gilmanov, R.A. Voldseth, G.R. Guntenspergen, and D.E. Naugle. 2005. Vulnerability of northern prairie wetlands to climate change. BioScience, 55(10): 863-872.

Johnson, W.C., B. Werner, G.R. Guntenspergen, R.A. Voldseth, B. Millett, D.E. Naugle, M. Tulbure, R.W.H. Carroll, J. Tracy, and C. Olawsky. 2010. Prairie wetland complexes as landscape functional units in a changing climate. BioScience, 60(2): 128-140.

Jones, W.M. 2004. Using vegetation to assess wetland condition: a multimetric approach for temporarily and seasonally flooded depressional wetlands in the northwestern glaciated plains ecoregion, Montana. Report to the Montana Department of Environmental Quality and the U.S. Environmental Protection Agency. Montana Natural Heritage Program, Helena, MT. 50 pp.

Jurik, T.W., S-C. Wang, and A.G. van der Valk. 1994. Effects of sediment load on seedling emergence from wetland seed banks. Wetlands, 14(3): 159-165. 
Kahara, S.N., R.M. Mockler, K.F. Higgins, S.R. Chipps, and R.R. Johnson. 2009. Spatiotemporal patterns of wetland occurrence in the Prairie Pothole Region of eastern South Dakota. Wetlands, 29(2): 678-689.

Kantrud, H.A., G.L. Krapu, and G.A. Swanson. 1989. Prairie basin wetlands of the Dakotas: a community profile. U.S. Fish and Wildlife Service, Biological Report 85 (7.28). Jamestown, ND: Northern Prairie Wildlife Research Center.

Kendy, E., C. Apse, and K. Blann. 2012. A practical guide to environmental flows for policy and planning. Available at: www.conserveonline.org/workspaces/eloha/documents/practicalguide-to-environmental-flows-for-policy.

Konrad, C.P., J.D. Olden, D.A. Lytle, T.S. Melis, J.C. Schmidt, E.N. Bray, M.C. Freeman, K.B. Gido, N.P. Hemphill, M.J. Kennard, L.E. McMullen, M.C. Mims, M. Pyron, C.T. Robinson, and J.G. Williams. 2011. Large-scale flow experiments for managing river systems. BioScience, 61(12): 948-959.

Krapu, G.L., P.A. Pietz, D.A. Brandt, R.R. Cox. 2003. Mallard brood movement, wetland use, and duckling survival during and following a prairie drought. The Journal of Wildlife Management, 70(5): 1436-1444.

Krapu, G.L., P.A. Pietz, D.A. Brandt and R.R. Cox. 2004. Does presence of permanent fresh water affect recruitment in prairie-nesting dabbling ducks? Journal of Wildlife Management, 68(2): 332-341

Krementz, D.G., K. Asante, and L.W. Naylor. 2011. Spring migration of mallards from Arkansas as determined by satellite telemetry. Journal of Fish and Wildlife Management, 2(2): 156168.

Labaugh, J.W., T.C. Winter, and D.O. Rosenberry. 1998. Hydrologic functions of prairie Wetlands. Great Plains Research, 8: 17-37.

Lake, P.S. 2003. Ecological effects of perturbation by drought in flowing waters. Freshwater Biology, 48(7): 1161-1172.

Larivière, S. and F. Messier. 2000. Habitat selection and use of edges by striped skunks in the Canadian prairies. Canadian Journal of Zoology, 78(3): 366-372.

Lavergne, S. and J. Molofsky. 2004. Reed canary grass (Phalaris arundinacea) as a biological model in the study of plant invasions. Critical Reviews in Plant Sciences, 23(5): 415-429.

Lemly, J. and L. Gilligan. 2012. North Platte river basin wetland profile and condition assessment. Report to Colorado Parks and Wildlife and the U.S. Environmental Protection Agency, Region 8. Colorado Natural Heritage Program, Fort Collins, CO. 173 pp. 
Lenhart, C.F., E.S. Verry, K.N. Brooks, and J.A. Magner. 2012. Adjustment of prairie pothole streams to land use, drainage and climate changes and consequences for turbidity impairment. River Research and Applications, 28(10): 1609-1619.

Lesica, P. and S. Miles. 2001. Tamarisk growth at the northern margin of its naturalized range in Montana, USA. Wetlands, 21(2): 240-246.

Loesch, C., S. Fields, and M. Estey. 2011. Decision support tools for prioritizing and targeting the conservation of grassland and wetland resources for breeding waterfowl in the U.S. Prairie Pothole Region - The "Thunderstorm Map." Poster presented at the 2011 Vision Conference for the National Wildlife Refuge System. Madison, WI.

Mabry, C. and C. Dettman. 2010. Odonata richness and abundance in relation to vegetation structure in restored and native wetlands of the Prairie Pothole Region, USA. Ecological Restoration, 28(4): 475-484.

Martin, D.B. 1985. Accumulation of sediment, nutrients, and cesium-137 in prairie potholes in cultivated and non-cultivated watersheds. In Persectives on Nonpoint Source Pollution, Proceedings of a National Conference. Kansas City, MO: Environmental Protection Agency, pp. 274-275.

Martin, D.B. and W.A. Hartman. 1987. The effect of cultivation on sediment composition and deposition in prairie pothole wetlands. Water, Air and Soil Pollution, 34(1): 45-53.

McCabe, G.D. and W.J. O'Brien. 2013. The effects of suspended silt on feeding and reproduction of daphnia pulex. American Midland Naturalist, 110(2): 324-337.

McIntyre, C., L. Vance, K. Newlon, and M. Burns. 2011. Milk, Marias and St. Mary's monitoring: developing a long-term rotating basin wetland assessment and monitoring strategy for Montana. Report to the United States Environmental Protection Agency. Montana Natural Heritage Program. Helena, Montana.

McManamay, R.A., D.J. Orth, and J. Kaufmann. 2011. Ecological response to flow alteration in the South Atlantic Region: A literature review and meta-analysis. Report to the Southeastern Aquatic Resources Partnership. Department of Fish and Wildlife Conservation, Virginia Tech. Blacksburg, VA. 62 pp.

McNaughton, S.J. 1986. On plants and herbivores. American Midland Naturalist, 128: 765-770.

Meyer, J.L., D.L. Strayer, J.B. Wallace, S.L. Eggert, G.S. Helfman, and N.E. Leonard. 2007. The contribution of headwater streams to biodiversity in river networks. Journal of the American Water Resources Association, 43(1): 86-103.

Mitsch, W.J. and J.G. Gosselink. 2000. Wetlands 3rd ed., New York: John Wiley \& Sons. 920 pp. 
Moore, I.D. and C.L. Larson. 1979. Effects of drainage projects on surface runoff from small depressional wetlands in the North-Central Region. WRRC Bulletin 99. Water Resources Research Center, St. Paul, MN.

Morrison, R.I.G. and J.P. Myers. 1989. Shorebird flyways in the New World. pp. 85-96, In H. Boyd and J.Y. Pirot, eds. Flyways and reserve networks for water birds. Slimbridge, Gloucester, UK: International Waterfowl and Wetlands Research Bureau. 109 pp.

Mullen, J.A., R.G. Bramblett, C.S. Guy, A.V. Zale, and D.W. Roberts. 2011. Determinants of fish assemblage structure in Northwestern Great Plains streams. Transactions of the American Fisheries Society, 140(2): 271-281.

Murkin, H. R., A. G. van der Valk and W. R. Clark (Eds.) 2000. Prairie Wetland Ecology: the Contribution of the Marsh Ecology Research Program. lowa State University Press, Ames, IA. $484 \mathrm{pp}$

Murkin, H.R. 1998. Freshwater functions and values of prairie wetlands. Great Plains Research, 8: 3-15.

Murkin, H.R., E.J. Murkin, and J.P. Ball. 1997. Avian habitat selection and prairie wetland dynamics: a 10-year experiment. Ecological Applications, 7(4): 1144-1159.

Naugle, D.E., R.R. Johnson, M.E. Estey, and K.F. Higgins. 2001. A landscape approach to conserving wetland bird habitat in the Prairie Pothole Region of Eastern South Dakota. Wetlands, 21(1): 1-17.

Neely, R.K. and J.L. Baker. 1989. Nitrogen and phosphorus dynamics and the fate of agricultural runoff. pp. 92-131. In: A.G. van der Valk, ed. Northern Prairie Wetlands. Iowa State University Press, Ames, IA. 414 pp.

Neill, C. 1995. Seasonal flooding, nitrogen mineralization and nitrogen utilization in a prairie marsh. Biogeochemistry, 30(3): 171-189.

Newlon, K.R., 2012. Southwest Montana Wetland Assessment: Developing a statewide assessment and monitoring strategy for Montana. Report to the U.S. Environmental Protection Agency. Montana Natural Heritage Program. Helena, MT.

Niemuth, N.D. and J.W. Solberg. 2003. Response of waterbirds to number of wetlands in the Prairie Pothole Region of North Dakota, U.S.A. Waterbirds, 26(2): 233-238.

Niemuth, N.D., M.E. Estey, R.E. Reynolds, C.R. Loesch, and W.A. Meeks. 2006. Use of wetlands by spring-migrant shorebirds in agricultural landscapes of North Dakota's Drift Prairie. Wetlands, 26(1): 30-39. 
Niemuth, N. A. Dahl, M.E. Estey and C.R. Loesch. 2007. Representation of landcover along breeding burd survey routes in the Northern Plains. Journal of Wildlife Management, 71(7): 2258-2265.

Niemuth, N., B. Wangler, and R.E. Reynolds. 2011. Spatial and temporal variation in wet area of wetland basins in the Prairie Pothole Region of North Dakota and South Dakota 19882007. Poster presented at the 2011 Vision Conference for the National Wildlife Refuge System. Madison, WI.

Norris R, S. Nichols, G. Ransom, A. Webb, M. Stewardson, P. Liston, and J. Mugodo. 2008. Causal criteria analysis methods manual: a systematic approach to evaluate causality in environmental science. Canberra, Australia: eWater Cooperative Research Centre.

North, A.K., 2000. Impact of nutrients and insecticide on algal production in a prairie wetland. Masters thesis. University of Manitoba, Winnipeg MB. 117 pp.

Ohrtman, M.K., S.A. Clay, D.E. Clay, E.M. Mousel, and A.J. Smart. 2011. Preventing saltcedar (Tamarix spp.) seedling establishment in the northern Prairie Pothole Region. Invasive Plant Science and Management, 4(4): 427-436.

Ojima, D.S., L. Garcia, E. Eigalli, K. Miller, T.G. Kittel, and J. Lackett. 1999. Potential climate change impacts on water resources in the Great Plains. Journal of the American Water Resources Association, 35: 1443-1454.

Poff, N.L., B.D. Richter, A.H. Arthington, S.E. Bunn, R.J. Naiman, E. Kendy, M. Acreman, C. Apse, B.P. Bledsoe, M.C. Freeman, J. Henriksen, R.B. Jacobson, J.G. Kennen, D.M. Merritt, J.H. O'Keeffe, J.D. Olden, K. Rogers, R.E. Tharme, and A. Warner. 2010. The ecological limits of hydrologic alteration (ELOHA): a new framework for developing regional environmental flow standards. Freshwater Biology, 55: 147-170.

Poiani, K.A. and W.C. Johnson. 1991.Global warming and prairie wetlands: Consequences for waterfowl habitat. BioScience 41: 611-618.

Preston, T.M., 2011. Reexamining saline contamination associated with oil and gas development in the Prairie Pothole Region, Sheridan County, MT. Masters thesis. Montana State University, Bozeman, MT. 168 pp.

Quist, M.C. and C.S. Guy. 2001. Growth and mortality of prairie stream fishes : relations with fish community and instream habitat characteristics. Ecology of Freshwater Fish, 10: 8896.

Reynolds, R.E., T.L. Shaffer, C.R. Loesch, and R.R. Cox. 2006. The Farm Bill and duck production in the Prairie Pothole Region: Increasing the benefits. Wildlife Society Bulletin, 34(4): 963974. 
Rose, C. and W.G. Crumpton. 1996. Effects of emerget macrophytes on dissolved oxygen dynamics in a Prairie Pothole wetland. Wetlands, 16(4): 495-502.

Rosso, J.J. and A. Fernández Cirelli. 2013. Effects of land use on environmental conditions and macrophytes in prairie lotic ecosystems. Limnologica, 43(1): 18-26.

Roth, J.L. and P.D. Capel. 2012. The hydrology of a drained topographical depression in an agricultural field in north-central lowa. Transactions of the ASABE, 55(5): 1801-1814

Schilling, K.E., T.M. Isenhart, J.A. Palmer, C.F. Wolter, and J. Spooner. 2011. Impacts of landcover change on suspended sediment transport in two agricultural watersheds. Journal of the American Water Resources Association, 47(4): 672-686.

Sexton, J.P., A. Sala, and K. Murray. 2006. Occurrence, persistence, and expansion of saltcedar (Tamarix Spp.) populations in the Great Plains of Montana. Western North American Naturalist, 66(1): 1-11.

Shaffer, J.A., G.A. Knutsen, R.E. Martin, and J.S. Brice. 2007. Pattern and potential causes of white-faced Ibis, Plegadis chihi, establishment in the northern prairie and parkland region of North America. Canadian Field Naturalist, 121(1): 46-57.

Shaw, D.A., G. van der Kamp, F.M. Conly, A. Pietroniro, and L. Martz. 2012. The fill-spill hydrology of prairie wetland complexes during drought and deluge. Hydrological Processes, 26: 3147-3156.

Shaw, J.R. and D.L. Cooper. 2008. Linkages among watersheds, stream reaches, and riparian vegetation in dryland ephemeral stream networks. Journal of Hydrology, 350(1-2): 68-82.

Shjieflo, J.B., 1968. Evapotranspiration and the water budget of prairie potholes in North Dakota. Professional Paper 585-B. United States Geological Survey. Reston, VA. 49 pp.

Silver, C.A. and S.M. Vamosi. 2012. Macroinvertebrate community composition of temporary prairie wetlands: a preliminary test of the effect of rotational grazing. Wetlands, 32(1): 185-197.

Simonovic, S.P. and K.M. Juliano. 2001. The role of wetlands during low frequency flooding events in the Red River basin. Canadian Water Resources Journal, 26(3): 377-395.

Skagen, S.K. 2006. Migration stopovers and the conservation of Arctic-breeding Calidridine sandpipers. The Auk, 123(2): 313-322.

Skagen, S.K., D.A. Granfors, and C.P. Melcher. 2008. On determining the significance of ephemeral continental wetlands to North American migratory shorebirds. The Auk, 125(1): 20-29. 
Smale, M.A. and C.F. Rabeni. 1995. Influences of hypoxia and hyperthermia on fish species composition in headwater streams. Transactions of the American Fisheries Society, 124(5): 711-725.

Smith, R.D., A. Ammann, C. Bartoldus, and M.M. Brinson. 1995. An approach for assessing wetland functions using hydrogeomorphic classification, reference wetlands, and functional indices. Technical Report WRP-DE-9. U.S. Army Corps of Engineers Waterways Experiment Station. Vicksburg, MS.

Spranza, J.J. and E.H. Stanley 2000. Condition, growth, and reproductive styles of fishes exposed to different environmental regimes in a prairie drainage. Environmental Biology of Fishes, 59: 99-109.

Stagliano, D.M., 2005. Aquatic community classification and ecosystem diversity in Montana's Missouri River watershed. Report for the Bureau of Land Management. Montana Natural Heritage Program. Helena, MT.

Steen, V.A. and A.N. Powell. 2012. Wetland selection by breeding and foraging black terns in the Prairie Pothole Region of the United States. The Condor, 114(1): 155-165.

Stephens, S.E., J.J. Rotella, M.S. Lindberg, M.L. Taper, and K. James. 2005. Duck nest survival in the Missouri Coteau of North Dakota : landscape effects at multiple spatial scales. Ecological Applications, 15(6): 2137-2149.

Stewart, R.E. and H.A. Kantrud. 1971. Classification of natural ponds and lakes in the Glaciated Prairie Region. Resource Publication 92. Bureau of Sport Fisheries and Wildlife, U.S. Fish and Wildlife Service. Washington, D.C.

Strand, K.A., S.R. Chipps, S.N. Kahara, K.F. Higgins, and S. Vaa. 2007. Patterns of prey use by lesser scaup Aythya affinis (Aves) and diet overlap with fishes during spring migration. Hydrobiologia, 598(1): 389-398.

Stromberg, J.C., A.F. Hazelton, and M.S. White. 2008. Plant species richness in ephemeral and perennial reaches of a dryland river. Biodiversity and Conservation, 18(3): 663-677.

Swanson, G.A., Meyer, M.I. \& Serie, J.R., 1974. Feeding ecology of breeding blue-winged teals. The Journal of Wildlife Management, 38(3), pp.396-407.

Tangen, B.A., M.G. Butler, and M.J. Ell. 2003. Weak correspondence between macroinvertebrate assemblages and land use in Prairie Pothole Region Wetlands, USA. Wetlands, 23(1): 104-115. 
U.S. Fish and Wildlife Service, 2007. Comprehensive conservation plan Medicine Lake National Wildlife Refuge Complex. Lakewood, Colorado: U.S. Department of the Interior, Fish and Wildlife Service, Mountain-Prairie Region. 184 pp.

US Fish and Wildlife Service. 2011. Comprehensive conservation plan: Bowdoin National Wildlife Refuge Complex. Lakewood, Colorado: U.S. Department of the Interior, Fish and Wildlife Service, Mountain-Prairie Region. 276 pp.

US Fish and Wildlife Service. 2012a. Draft Comprehensive Conservation Plan and Environmental Assessment, Benton Lake National Wildlife Refuge Complex. Lakewood, Colorado : U.S. Department of the Interior, Fish and Wildlife Service, Mountain-Prairie Region. 366 pp.

US Fish and Wildlife Service. 2012b. Final Comprehensive conservation plan and environmental impact statement: Charles M. Russell National Widlife Refuge, UL Bend National Wildlife Refuge. Volume 1. Lakewood, Colorado: U.S. Department of the Interior, Fish and Wildlife Service, Mountain-Prairie Region. 468 pp.

Van der Kamp, G. and M. Hayashi. 1998. The groundwater recharge function of small wetlands in the semi-arid northern prairies. Great Plains Research, 8: 39-56.

Van der Kamp, G., M. Hayashi, and D. Gallen. 2003. Comparing the hydrology of grassed and cultivated catchments in the semi-arid Canadian prairies. Hydrological Processes, 17(3): 559-575.

Van der Kamp, G., W.J. Stolte, and R.G. Clark. 1999. Drying out of small prairie wetlands after conversion of their catchments from cultivation to permanent brome grass. Hydrological Sciences, 44(3): 387-397.

Van der Kamp, G., M. Rigge, N.H. Troelstrup, A.J. Smart, and B. Wylie. 2013. Detecting channel riparian vegetation response to best management practices implementation in ephemeral streams with the use of SPOT high-resolution visible imagery. Rangeland Ecology \& Management, 66(1): 63-70.

Van der Valk, A.G. 2005. Water-level fluctuations in North American prairie wetlands. Hydrobiologia, 539(1): 171-188.

Vance, L.K. 2009. Geographically isolated wetlands and intermittent/ephemeral streams in Montana: extent, distribution and function. Report to the Montana Department of Environmental Quality and the U.S. Environmental Protection Agency. Montana Natural Heritage Program. Helena, MT.

Vance, L.K., G.M. Kudray, and S.V. Cooper. 2006. Crosswalking National Wetland Inventory attributes to hydrogeomorpic functions and vegetation communities: a pilot study in the Gallatin Valley, Montana. Report to the Montana Department of Environmental Quality 
and the United States Environmental Protection Agency. Montana Natural Heritage Program. Helena, Montana.

Voldseth, R.A., W.C. Johnson, G.R. Guntenspergen, T. Gilmanov, and B.V. Millett. 2009. Adaptation of farming practices could buffer effects of climate change on northern prairie wetlands. Wetlands, 29(2): 635-647.

Voldseth, R.A., W.C. Johnson, T. Gilmanov., GIR. Guntenspergen, and B.V. Millett. 2007. Model estimation of land-use effects on water levels of northern prairie wetlands. Ecological Applications, 17(2): 527-40.

Walker, J., J.J. Rotella, J.H. Schmidt, C.R. Loesch, R.E. Reynolds, M.S. Lindberg, J.K. Ringelman, and S.E. Stephens. 2013. Distribution of duck broods relative to habitat characteristics in the Prairie Pothole Region. The Journal of Wildlife Management, 77(2): 392-404.

Weller, M.W. 1988. Issues and approaches in assessing cumulative impacts on waterbird habitat in wetlands. Environmental Management 12:695-701.

Werner, K.J. and J.B. Zedler. 2002. How sedge meadow soils, microtopography, and vegetation respond to sedimentation. Wetlands, 22(3): 451-466.

Wiewel, A.S., W.R. Clark, and M.A. Sovada. 2007. Assessing small mammal abundance with track-tube indices and mark recapture. Journal of Mammology, 88(1): 250-260.

Winston, M.R., C.M. Taylor, and J. Pigg. 1991. Upstream extirpation of four minnow species due to damming of a prairie stream. Transactions of the American Fisheries Society, 120(1): 98105.

Winter, T.C. 1989. Hydrologic studies of wetlands in the northern prairie. pp 16-54. In: A. G. van der Valk, ed. Northern Prairie Wetlands. Iowa State University Press. Ames, IA. 414 pp.

Winter, T.C. and D.O. Rosenberry. 1998. Hydrology of prairie pothole wetlands during drought and deluge. Climatic Change, 40: 189-209.

Woo, M.K. and R.D. Rowsell. 1993. Hydrology of a prairie slough. Journal of Hydrology, 146: 175-207.

Zeng, T., K.L. Ziegelgruber, Y-P. Chin, and W.A. Arnold. 2011. Pesticide processing potential in prairie pothole porewaters. Environmental Science \& Technology, 45: 6814-6822.

Zimmer, K.D., M.A. Hanson, and M.G. Butler. 2003. Interspecies relationships, community structure, and factors influencing abundance of submerged macrophytes in prairie wetlands. Wetlands, 23(4): 717-728. 


\section{APPENDICES}




\section{Appendix A. Approximate crosswalk between classification schemes}

\begin{tabular}{|c|c|c|c|}
\hline Stewart and Kantrud ${ }^{1}$ & Cowardin/USFWS & Natureserve Ecological System & Army Corps of Engineers HGM \\
\hline I. Ephemeral pond & Not a wetland ${ }^{3}$ & Great Plains Mixed Grass Prairie & Lacking wetland hydrology, soils and vegetation \\
\hline II. Temporary Pond & PEMA & Great Plains Prairie Pothole & Temporary/Seasonally Ponded Prairie Pothole Systems \\
\hline Fresh & & Great Plains Prairie Pothole & \\
\hline Brackish & & Great Plains Prairie Pothole & \\
\hline III. Seasonal Ponds (and Lakes) & PEMC & & \\
\hline Fresh & & Great Plains Prairie Pothole & Temporary/Seasonally Ponded Prairie Pothole Systems \\
\hline Slighly Brackish & & Great Plains Prairie Pothole & \\
\hline Moderately brackish & & Great Plains Prairie Pothole & \\
\hline IV. Semi-permanent Ponds (and Lakes) & PEMF, PEMG; PUS (C and G), & & \\
\hline Fresh & PABF & Great Plains Open Depression Wetland & Depressional Wetlands ${ }^{2}$ \\
\hline Slighly Brackish & & Great Plains (Open or Closed) Depression Wetland & \\
\hline Moderately brackish & & Great Plains Closed Depression Wetland & \\
\hline Brackish & & Great Plains Saline Depression Wetland & \\
\hline Saline & & Great Plains Saline Depression Wetland & \\
\hline IV. Permanent Ponds (and Lakes) & PEMH, PEMG, PABH & & Not defined \\
\hline Slighly Brackish & & NA Arid West Emergent Marsh & \\
\hline Moderately brackish & & NA Arid West Emergent Marsh & \\
\hline Brackish & & NA Arid West Emergent Marsh & \\
\hline Saline & & Great Plains Saline Depression Wetland & \\
\hline V. Alkali Ponds (and Lakes) & PEMA, PEMC, PUSA, PUSC & Great Plains Saline Depression Wetland & \\
\hline VI. Fen Ponds & & & \\
\hline
\end{tabular}

1. The Stewart and Kantrud scheme was intended as a regional typology, and describes the entire wetland based on duration of flooding, whereas Cowardin was intended as a national classification, and describes wetlands at the habitat component level to facilita te inventoryand mapping. In the Cowardin system, a single wetland basin may have two or more habitat components, usually defined by water regime. Natureserve's ecological systems classification (Comer et al. 2003) also aggregates components into a single class.

2. In the HGM Regional Guidebook (Gilbert 2006), Prairie Potholes are specifically defined as hydrologically domi nated by surface runoff; wetlands with a groundwater source are the refore simply depressional wetlands

3. A shallow depression with ephemeral ponding in its center, or a swale that transports overland flow, would not be flooded for long enough to be a wetland in the Cowardin system. 


\section{Appendix B. Keywords and search strings used in database searches}

\section{DATABASE}

\section{BioOne}

Prairie Pothole* AND Montana

Prairie Pothole* AND (wetland OR habitat OR hydrol* OR aquatic* OR water* OR intermittent OR ephemeral OR stream OR waterfowl OR duck* OR *bird* OR amphibian* OR reptile* or mammal* or nest* OR macroinvertebrate* OR agriculture* OR land use OR development)

Prairie AND (wetland OR habitat OR hydrol* OR aquatic* OR water* OR intermittent OR ephemeral OR stream OR waterfowl OR duck* OR *bird* OR amphibian* OR reptile* or mammal* or nest* OR macroinvertebrate* OR agriculture* OR land use OR development)

Pothole AND (wetland OR habitat OR hydrol* OR aquatic* OR water* OR intermittent OR ephemeral OR stream OR waterfowl OR duck* OR *bird* OR amphibian* OR reptile* or mammal* or nest* OR macroinvertebrate* OR agriculture* OR land use OR development)

Northwestern Glaciated Plains

Prairie Pothole Region

Wetland* AND (Montana OR North Dakota OR South Dakota OR Alberta OR Manitoba OR Saskatchewan Intermittent OR Ephemeral AND stream* \{Species name OR Guild ${ }^{8}$ AND (wetland* OR pothole* OR habitat* OR ecology*)

\section{Environment Complete}

Prairie Pothole* AND Montana

Prairie Pothole* AND (wetland OR hydrol* OR aquatic* OR water* OR intermittent OR ephemeral OR stream OR waterfowl OR duck* OR *bird* OR amphibian* OR reptile* or mammal* or nest* OR macroinvertebrate* OR agriculture* OR land use OR development)

\footnotetext{
${ }^{8}$ Species names and guilds arelisted in Appendix C
} 
Prairie AND (wetland OR hydrol* OR aquatic* OR water* OR intermittent OR ephemeral OR stream OR waterfowl OR duck* OR *bird* OR amphibian* OR reptile* or mammal* or nest* OR macroinvertebrate* OR agriculture* OR land use OR development)

Pothole AND (wetland OR hydrol* OR aquatic* OR water* OR intermittent OR ephemeral OR stream OR waterfowl OR duck* OR *bird* OR amphibian* OR reptile* or mammal* or nest* OR macroinvertebrate* OR agriculture* OR land use OR development)

Northwestern Glaciated Plains

Prairie Pothole Region

Wetland* AND (Montana OR North Dakota OR South Dakota OR Alberta OR Manitoba OR Saskatchewan

\{Species name OR Guild\} AND (wetland* OR pothole* OR habitat* OR ecology*) 
Appendix C: Faunal species associated with PPR wetland and streams

\begin{tabular}{|c|c|c|c|c|}
\hline $\begin{array}{l}\text { Global/State } \\
\text { Rank }\end{array}$ & $\begin{array}{l}\text { Common } \\
\text { Name }\end{array}$ & Scientific Name & $\begin{array}{l}\text { Distribution } \\
\text { Status }\end{array}$ & Guild \\
\hline G5/S3 & $\begin{array}{l}\text { Great Blue } \\
\text { Heron }\end{array}$ & Ardea herodias & $\begin{array}{l}\text { Resident } \\
\text { Year Round }\end{array}$ & Colonial nesting waterbirds \\
\hline G4/S3B & $\begin{array}{l}\text { American } \\
\text { Bittern }\end{array}$ & Botaurus lentiginosus & $\begin{array}{l}\text { Migratory } \\
\text { Summer } \\
\text { Breeder }\end{array}$ & Colonial nesting waterbirds \\
\hline G4/S3B & Black Tern & Chlidonias niger & $\begin{array}{l}\text { Migratory } \\
\text { Summer } \\
\text { Breeder }\end{array}$ & Colonial nesting waterbirds \\
\hline G5/S2B & Caspian Tern & Hydroprogne caspia & $\begin{array}{l}\text { Migratory } \\
\text { Summer } \\
\text { Breeder }\end{array}$ & Colonial nesting waterbirds \\
\hline G4G5/S3B & Franklin's Gull & Leucophaeus pipixcan & $\begin{array}{l}\text { Migratory } \\
\text { Summer } \\
\text { Breeder }\end{array}$ & Colonial nesting waterbirds \\
\hline G5/S5B & $\begin{array}{l}\text { Double- } \\
\text { crested } \\
\text { Cormorant }\end{array}$ & Phalacrocorax auritus & $\begin{array}{l}\text { Migratory } \\
\text { Summer } \\
\text { Breeder }\end{array}$ & Colonial nesting waterbirds \\
\hline G5/S3B & $\begin{array}{l}\text { White-faced } \\
\text { Ibis }\end{array}$ & Plegadis chihi & $\begin{array}{l}\text { Migratory } \\
\text { Summer } \\
\text { Breeder }\end{array}$ & Colonial nesting waterbirds \\
\hline G5/S5B & Eared Grebe & Podiceps nigricollis & $\begin{array}{l}\text { Migratory } \\
\text { Summer } \\
\text { Breeder }\end{array}$ & Colonial nesting waterbirds \\
\hline G5/S3B & Common Tern & Sterna hirundo & $\begin{array}{l}\text { Migratory } \\
\text { Summer } \\
\text { Breeder }\end{array}$ & Colonial nesting waterbirds \\
\hline G4/S1B & Least Tern & Sternula antillarum & $\begin{array}{l}\text { Migratory } \\
\text { Summer } \\
\text { Breeder }\end{array}$ & Colonial nesting waterbirds \\
\hline G5/S5B & Wood Duck & Aix sponsa & $\begin{array}{l}\text { Resident } \\
\text { Year Round }\end{array}$ & Dabbling waterfowl \\
\hline G5/S5B & $\begin{array}{l}\text { Northern } \\
\text { Pintail }\end{array}$ & Anas acuta & $\begin{array}{l}\text { Resident } \\
\text { Year Round }\end{array}$ & Dabbling waterfowl \\
\hline G5/S5B & $\begin{array}{l}\text { American } \\
\text { Wigeon }\end{array}$ & Anas americana & $\begin{array}{l}\text { Resident } \\
\text { Year Round }\end{array}$ & Dabbling waterfowl \\
\hline G5/S5B & $\begin{array}{l}\text { Northern } \\
\text { Shoveler }\end{array}$ & Anas clypeata & $\begin{array}{l}\text { Migratory } \\
\text { Summer } \\
\text { Breeder }\end{array}$ & Dabbling waterfowl \\
\hline G5/S5B & $\begin{array}{l}\text { Green-winged } \\
\text { Teal }\end{array}$ & Anas crecca & $\begin{array}{l}\text { Resident } \\
\text { Year Round }\end{array}$ & Dabbling waterfowl \\
\hline G5/S5B & $\begin{array}{l}\text { Blue-winged } \\
\text { Teal }\end{array}$ & Anas discors & $\begin{array}{l}\text { Migratory } \\
\text { Summer } \\
\text { Breeder }\end{array}$ & Dabbling waterfowl \\
\hline Global/State & Common & Scientific Name & Distribution & Guild \\
\hline
\end{tabular}




\begin{tabular}{|c|c|c|c|c|}
\hline Rank & Name & & Status & \\
\hline G5/S5 & Mallard & Anas platyrhynchos & $\begin{array}{l}\text { Resident } \\
\text { Year Round }\end{array}$ & Dabbling waterfowl \\
\hline G5/S5B & Gadwall & Anas strepera & $\begin{array}{l}\text { Resident } \\
\text { Year Round }\end{array}$ & Dabbling waterfowl \\
\hline G5/S5B & Canada Goose & Branta canadensis & $\begin{array}{l}\text { Resident } \\
\text { Year Round }\end{array}$ & Dabbling waterfowl \\
\hline G5/S4N & Snow Goose & Chen caerulescens & $\begin{array}{l}\text { Common } \\
\text { Migrant }\end{array}$ & Dabbling waterfowl \\
\hline G5/S5B & Lesser Scaup & Aythya affinis & $\begin{array}{l}\text { Resident } \\
\text { Year Round }\end{array}$ & Diving waterfowl \\
\hline G5/S5B & Redhead & Aythya americana & $\begin{array}{l}\text { Migratory } \\
\text { Summer } \\
\text { Breeder }\end{array}$ & Diving waterfowl \\
\hline G5/S5B & $\begin{array}{l}\text { Ring-necked } \\
\text { Duck }\end{array}$ & Aythya collaris & $\begin{array}{l}\text { Resident } \\
\text { Year Round }\end{array}$ & Diving waterfowl \\
\hline G5/S5B & Canvasback & Aythya valisineria & $\begin{array}{l}\text { Migratory } \\
\text { Summer } \\
\text { Breeder }\end{array}$ & Diving waterfowl \\
\hline G5/S5B & Bufflehead & Bucephala albeola & $\begin{array}{l}\text { Resident } \\
\text { Year Round }\end{array}$ & Diving waterfowl \\
\hline G5/S5 & $\begin{array}{l}\text { Common } \\
\text { Goldeneye }\end{array}$ & Bucephala clangula & $\begin{array}{l}\text { Resident } \\
\text { Year Round }\end{array}$ & Diving waterfowl \\
\hline G5/S4 & $\begin{array}{l}\text { Hooded } \\
\text { Merganser }\end{array}$ & Lophodytes cucullatus & $\begin{array}{l}\text { Resident } \\
\text { Year Round }\end{array}$ & Diving waterfowl \\
\hline G5/S5B & $\begin{array}{l}\text { Common } \\
\text { Merganser }\end{array}$ & Mergus merganser & $\begin{array}{l}\text { Resident } \\
\text { Year Round }\end{array}$ & Diving waterfowl \\
\hline G5/S5B & Ruddy Duck & Oxyura jamaicensis & $\begin{array}{l}\text { Migratory } \\
\text { Summer } \\
\text { Breeder }\end{array}$ & Diving waterfowl \\
\hline G5/S5B & $\begin{array}{l}\text { Red-winged } \\
\text { Blackbird }\end{array}$ & Agelaius phoeniceus & $\begin{array}{l}\text { Resident } \\
\text { Year Round }\end{array}$ & Grassland birds \\
\hline G5/S3B & $\begin{array}{l}\text { Nelson's } \\
\text { Sparrow }\end{array}$ & Ammodramus nelsoni & $\begin{array}{l}\text { Migratory } \\
\text { Summer } \\
\text { Breeder }\end{array}$ & Grassland birds \\
\hline G5/S5B & Marsh Wren & Cistothorus palustris & $\begin{array}{l}\text { Resident } \\
\text { Year Round }\end{array}$ & Grassland birds \\
\hline G5/S3B & Bobolink & Dolichonyx oryzivorus & $\begin{array}{l}\text { Migratory } \\
\text { Summer } \\
\text { Breeder }\end{array}$ & Grassland birds \\
\hline G5/S3B & Veery & Catharusfuscescens & $\begin{array}{l}\text { Migratory } \\
\text { Summer } \\
\text { Breeder }\end{array}$ & Other \\
\hline G5/S4B & $\begin{array}{l}\text { Willow } \\
\text { Flycatcher }\end{array}$ & Empidonax traillii & $\begin{array}{l}\text { Migratory } \\
\text { Summer } \\
\text { Breeder }\end{array}$ & Other \\
\hline $\begin{array}{l}\text { Global/State } \\
\text { Rank }\end{array}$ & $\begin{array}{l}\text { Common } \\
\text { Name }\end{array}$ & Scientific Name & $\begin{array}{l}\text { Distribution } \\
\text { Status }\end{array}$ & Guild \\
\hline
\end{tabular}




\begin{tabular}{|c|c|c|c|c|}
\hline G5/S5B,S2N & Sandhill Crane & Grus canadensis & $\begin{array}{l}\text { Migratory } \\
\text { Summer } \\
\text { Breeder }\end{array}$ & Other \\
\hline G5/S5B & $\begin{array}{l}\text { Belted } \\
\text { Kingfisher }\end{array}$ & Megaceryle alcyon & $\begin{array}{l}\text { Resident } \\
\text { Year Round }\end{array}$ & Other \\
\hline G5/S3B & $\begin{array}{l}\text { Red-headed } \\
\text { Woodpecker }\end{array}$ & Melanerpes erythrocephalus & $\begin{array}{l}\text { Migratory } \\
\text { Summer } \\
\text { Breeder }\end{array}$ & Other \\
\hline G5/S5B & $\begin{array}{l}\text { Spotted } \\
\text { Sandpiper }\end{array}$ & Actitis macularius & $\begin{array}{l}\text { Migratory } \\
\text { Summer } \\
\text { Breeder }\end{array}$ & Shorebirds \\
\hline G5/SNA & $\begin{array}{l}\text { Stilt } \\
\text { Sandpiper }\end{array}$ & Calidris himantopus & $\begin{array}{l}\text { Common } \\
\text { Migrant }\end{array}$ & Shorebirds \\
\hline G5/SNA & $\begin{array}{l}\text { Least } \\
\text { Sandpiper }\end{array}$ & Calidris minutilla & $\begin{array}{l}\text { Common } \\
\text { Migrant }\end{array}$ & Shorebirds \\
\hline G5/SNA & $\begin{array}{l}\text { Semipalmated } \\
\text { Sandpiper }\end{array}$ & Calidris pusilla & $\begin{array}{l}\text { Common } \\
\text { Migrant }\end{array}$ & Shorebirds \\
\hline $\mathrm{G} 3 / \mathrm{S} 2 \mathrm{~B}$ & Piping Plover & Charadrius melodus & $\begin{array}{l}\text { Migratory } \\
\text { Summer } \\
\text { Breeder }\end{array}$ & Shorebirds \\
\hline G5/S3B & $\begin{array}{l}\text { Black-necked } \\
\text { Stilt }\end{array}$ & Himantopus mexicanus & $\begin{array}{l}\text { Migratory } \\
\text { Summer } \\
\text { Breeder }\end{array}$ & Shorebirds \\
\hline G5/SNA & $\begin{array}{l}\text { Long-billed } \\
\text { Dowitcher }\end{array}$ & Limnodromus scolopaceus & $\begin{array}{l}\text { Passage } \\
\text { Migrant }\end{array}$ & Shorebirds \\
\hline G5/S4B & $\begin{array}{l}\text { Marbled } \\
\text { Godwit }\end{array}$ & Limosa fedoa & $\begin{array}{l}\text { Migratory } \\
\text { Summer } \\
\text { Breeder }\end{array}$ & Shorebirds \\
\hline G5/S4B & $\begin{array}{l}\text { Wilson's } \\
\text { Phalarope }\end{array}$ & Phalaropus tricolor & $\begin{array}{l}\text { Migratory } \\
\text { Summer } \\
\text { Breeder }\end{array}$ & Shorebirds \\
\hline G5/S4B & $\begin{array}{l}\text { American } \\
\text { Avocet }\end{array}$ & Recurvirostra americana & $\begin{array}{l}\text { Migratory } \\
\text { Summer } \\
\text { Breeder }\end{array}$ & Shorebirds \\
\hline G5/S4B & Willet & Tringa semipalmata & $\begin{array}{l}\text { Migratory } \\
\text { Summer } \\
\text { Breeder }\end{array}$ & Shorebirds \\
\hline G5/S3B & Clark's Grebe & Aechmophorus clarkii & $\begin{array}{l}\text { Migratory } \\
\text { Summer } \\
\text { Breeder }\end{array}$ & Waterbirds \\
\hline G5/S4B & $\begin{array}{l}\text { Western } \\
\text { Grebe }\end{array}$ & Aechmophorus occidentalis & $\begin{array}{l}\text { Migratory } \\
\text { Summer } \\
\text { Breeder }\end{array}$ & Waterbirds \\
\hline G4/S3B & Yellow Rail & Coturnicops noveboracensis & Accidental & Waterbirds \\
\hline $\begin{array}{l}\text { Global/State } \\
\text { Rank }\end{array}$ & $\begin{array}{l}\text { Common } \\
\text { Name }\end{array}$ & Scientific Name & $\begin{array}{l}\text { Distribution } \\
\text { Status }\end{array}$ & Guild \\
\hline
\end{tabular}




\begin{tabular}{|c|c|c|c|c|}
\hline G5/S5B & $\begin{array}{l}\text { American } \\
\text { Coot }\end{array}$ & Fulica americana & $\begin{array}{l}\text { Resident } \\
\text { Year Round }\end{array}$ & Waterbirds \\
\hline G5/S3B & Horned Grebe & Podiceps auritus & $\begin{array}{l}\text { Migratory } \\
\text { Summer } \\
\text { Breeder }\end{array}$ & Waterbirds \\
\hline G5/S4B & $\begin{array}{l}\text { Red-necked } \\
\text { Grebe }\end{array}$ & Podiceps grisegena & $\begin{array}{l}\text { Migratory } \\
\text { Summer } \\
\text { Breeder }\end{array}$ & Waterbirds \\
\hline G5/S5B & $\begin{array}{l}\text { Pied-billed } \\
\text { Grebe }\end{array}$ & Podilymbus podiceps & $\begin{array}{l}\text { Resident } \\
\text { Year Round }\end{array}$ & Waterbirds \\
\hline G5/S5B & Sora & Porzana carolina & $\begin{array}{l}\text { Migratory } \\
\text { Summer } \\
\text { Breeder }\end{array}$ & Waterbirds \\
\hline G5/S5B & Virginia Rail & Rallus limicola & $\begin{array}{l}\text { Migratory } \\
\text { Summer } \\
\text { Breeder }\end{array}$ & Waterbirds \\
\hline G5/S4 & $\begin{array}{l}\text { Barred Tiger } \\
\text { Salamander }\end{array}$ & Ambystoma mavortium & $\begin{array}{l}\text { Resident } \\
\text { Year Round }\end{array}$ & Amphibian \\
\hline G5/S4 & $\begin{array}{l}\text { Woodhouse's } \\
\text { Toad }\end{array}$ & Anaxyrus woodhousii & $\begin{array}{l}\text { Resident } \\
\text { Year Round }\end{array}$ & Amphibian \\
\hline G5/S3 & $\begin{array}{l}\text { Plains } \\
\text { Spadefoot }\end{array}$ & Spea bombifrons & $\begin{array}{l}\text { Resident } \\
\text { Year Round }\end{array}$ & Amphibian \\
\hline G5/S4 & $\begin{array}{l}\text { Boreal Chorus } \\
\text { Frog }\end{array}$ & Pseudacris maculata & $\begin{array}{l}\text { Resident } \\
\text { Year Round }\end{array}$ & Amphibian \\
\hline G5/S1,S4 & $\begin{array}{l}\text { Northern } \\
\text { Leopard Frog }\end{array}$ & Lithobates pipiens & $\begin{array}{l}\text { Resident } \\
\text { Year Round }\end{array}$ & Amphibian \\
\hline G5/S4 & $\begin{array}{l}\text { Northern } \\
\text { Painted Turtle }\end{array}$ & Chrysemys picta & $\begin{array}{l}\text { Resident } \\
\text { Year Round }\end{array}$ & Reptile \\
\hline G5/S2 & $\begin{array}{l}\text { Smooth } \\
\text { Green Snake }\end{array}$ & Opheodrys vernalis & $\begin{array}{l}\text { Resident } \\
\text { Year Round }\end{array}$ & Reptile \\
\hline G5/S2S3 & $\begin{array}{l}\text { Eastern Red } \\
\text { Bat }\end{array}$ & Lasiurus borealis & $\begin{array}{l}\text { Migratory } \\
\text { Summer } \\
\text { Breeder }\end{array}$ & Mammal \\
\hline G5/S4 & Least Weasel & Mustela nivalis & $\begin{array}{l}\text { Resident } \\
\text { Year Round }\end{array}$ & Mammal \\
\hline G5/S5 & $\begin{array}{l}\text { American } \\
\text { Mink }\end{array}$ & Mustela vison & $\begin{array}{l}\text { Resident } \\
\text { Year Round }\end{array}$ & Mammal \\
\hline G5/S5 & $\begin{array}{l}\text { Common } \\
\text { Muskrat }\end{array}$ & Ondatra zibethicus & $\begin{array}{l}\text { Resident } \\
\text { Year Round }\end{array}$ & Mammal \\
\hline $\begin{array}{l}\text { Global/State } \\
\text { Rank }\end{array}$ & $\begin{array}{l}\text { Common } \\
\text { Name }\end{array}$ & Scientific Name & $\begin{array}{l}\text { Distribution } \\
\text { Status }\end{array}$ & Guild \\
\hline
\end{tabular}




\begin{tabular}{|l|l|l|l|l|}
\hline G5/S1S3 & Arctic Shrew & Sorex arcticus & $\begin{array}{l}\text { Resident } \\
\text { Year Round }\end{array}$ & Mammal \\
\hline G5/S5 & Dusky Shrew & Sorex monticolus & $\begin{array}{l}\text { Resident } \\
\text { Year Round }\end{array}$ & Mammal \\
\hline G4/S2S3 & Dwarf Shrew & Sorex nanus & $\begin{array}{l}\text { Resident } \\
\text { Year Round }\end{array}$ & Mammal \\
\hline G5/S2 & $\begin{array}{l}\text { Meadow } \\
\text { Jumping } \\
\text { Mouse }\end{array}$ & Zapus hudsonius & $\begin{array}{l}\text { Resident } \\
\text { Year Round }\end{array}$ & Mammal \\
\hline G5/S4 & $\begin{array}{l}\text { Brassy } \\
\text { minnow }\end{array}$ & Hybognathus hankinsoni & Fish & Fish \\
\hline G5/S4 & $\begin{array}{l}\text { Brook } \\
\text { stickleback }\end{array}$ & Culaea inconstans & & Fish \\
\hline G5/S3 & $\begin{array}{l}\text { Northern } \\
\text { redbelly dace }\end{array}$ & Chrosomus eos & & Fish \\
\hline G5/S2 & Pearl dace & Margariscus margarita & & \\
\hline
\end{tabular}




\section{Appendix D. Number of sources describing ecological change in wetland function following hydrologic alterations}

Function

Water storage

Groundwater recharge

Streamflow maintenance

\author{
Change vector
}

Agriculture

Channelization

Climate change

Dams or impoundments

Diversions

Draining or ditching

Excavation

Land cover change

Overgrazing

Roads or culverts

Agriculture

Channelization

Climate change

Dams or impoundments

Diversions

Draining or ditching

Excavation

Groundwater extraction

Land cover change

Overgrazing

Roads or culverts
Groundwater extraction

\author{
\# of sources
}

7

1

2

9

2

1

Agriculture $\quad 1$

Channelization $\quad 1$

Climate change $\quad 2$

Dams or impoundments 1

Diversions 1

Draining or ditching 1

Excavation 1

Land cover change $\quad 2$

Overgrazing 1 
Flood mitigation

Plant community maintenance

Faunal habitat

Biodiversity
Agriculture

Dams or impoundments

Draining or ditching

Overgrazing

Agriculture

Channelization

Climate change

Dams or impoundments

Diversions

Draining or ditching

Excavation

Groundwater extraction

Land cover change

Overgrazing

Roads or culverts

Agriculture

Channelization

Climate change

Dams or impoundments

Diversions

Draining or ditching

Excavation

Land cover change

Overgrazing

Roads or culverts

Agriculture

Channelization

Climate change

Dams or impoundments

Diversions

Draining or ditching

Excavation

Groundwater extraction

Land cover change

Overgrazing

Roads or culverts
39

5

12

12

32

24

2

2

1

5

2

12

4

2

6

13

2

2

13

3

6

2 
